Tilburg Law and Economics Center (TILEC) Law and Economics

Discussion Paper No. 2011-008

$$
\sim \text { and }
$$

Tilburg Law School Legal Studies

Research Paper No. 01/2011

October 26, 2010

\title{
Judicial Review in European Union Competition Law: A Quantitative and Qualitative Assessment
}

\author{
Damien Geradin \\ Tilburg University - Tilburg Law and Economics Center (TILEC) \\ University of Michigan Law School \\ Tilburg Law School
}

Nicolas Petit

University of Liege

This paper can be downloaded free of charge from the

Social Science Research Network at:

http://ssrn.com/abstract $=1698342$ 

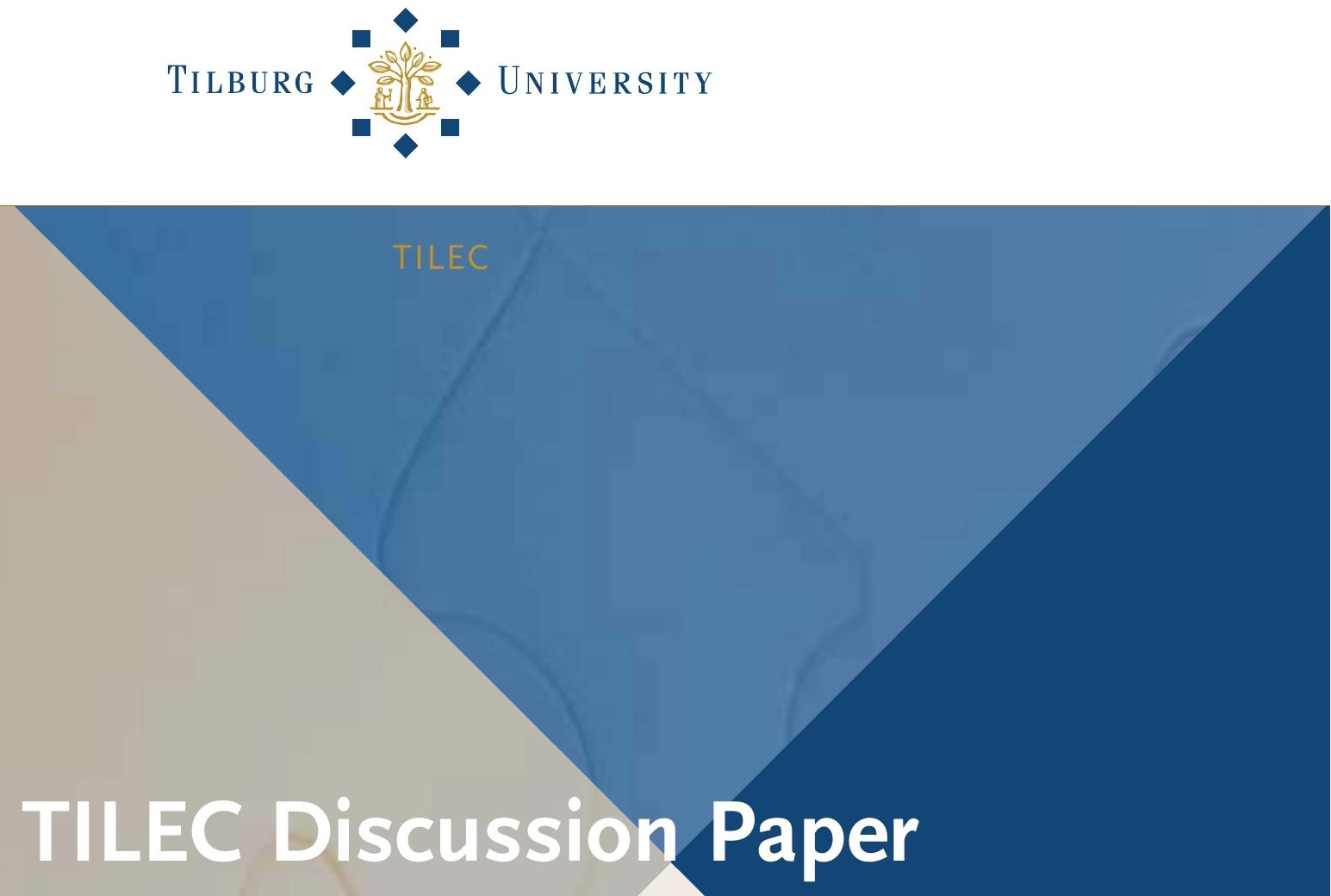

\title{
JUDICIAL REVIEW IN EUROPEAN UNION COMPETITION LAW: \\ A QUANTITATIVE AND QUALITATIVE ASSESSMENT
}

\section{By}

\author{
Damien Geradin and Nicolas Petit
}

February 2011

ISSN 1572-4042

http://ssrn.com/abstract=1698342 


\title{
JUDICIAL REVIEW IN EUROPEAN UNION COMPETITION LAW: A QUANTITATIVE AND QUALITATIVE ASSESSMENT
}

\author{
Damien Geradin and Nicolas Petit ${ }^{(*)}$
}

\begin{abstract}
Ever since the creation of the General Court ("GC"), the effectiveness of judicial review in European Union ("EU") competition cases has sparked intense scholarly debates. This paper seeks to further contribute to this discussion in three ways. First, it devotes some space to fundamental, yet often overlooked questions, such as the goals or functions of judicial review and why judicial review of administrative decisions is important; particularly so in competition law matters. Second, this paper attempts to throw some empirical light on the GC's judicial review of European Commission ("Commission") decisions in the field of competition law. Third, it places a specific emphasis on the particular situation of abuse of dominance law, where the GC has exercised its judicial review power with more restraint than in other areas of competition law (such as restrictive agreements and mergers).
\end{abstract}

With these goals in mind, this paper follows a five-stage progression. First, on the basis of a survey of the relevant legal, economic and political science literature, it defines the functions of judicial review and identifies a set of indicators which can be used to assess the performance of the GC's judicial scrutiny (Part I). Second, it explains why judicial review in EU competition law cases is of critical importance notably given the institutional and procedural deficiencies of the EU enforcement structure (Part II). Third, it discusses the nature and standard of review currently applied by the GC with a particular focus on the degree to which the GC is willing to review "complex economic matters" (Part III). Fourth, it provides some quantitative data on the case-law of the GC to assess whether several goals or functions attributed to judicial review by the scientific literature are met (Part IV). Finally, this paper takes a closer look at the (controversial) case-law of the GC in the field of Article 102 of the Treaty on the Functioning of the European Union ("TFEU") (Part V).

Keywords: competition, judicial review, standards of review, EU, General Court, European Commission, abuse of dominance, judicial restraint, European Court of Justice, cartels, mergers, enforcement

JEL Codes: K10; K21; K4; L40

\footnotetext{
${ }^{(*)}$ Damien Geradin is a Professor of Competition Law and Economics at Tilburg University TILEC, a William W. Cook Global Law Professor at the University of Michigan Law School and a visiting Professor at the College of Europe, Bruges. He is also a partner at Covington \& Burling. Nicolas Petit is a Professor at University of Liège (ULg) and the Director of the GCLC at the College of Europe, Bruges. The authors would like to thank Elise Provost for her excellent research assistance on Part IV of this paper. This paper was sponsored in part by the U.S. Chamber of Commerce's Global Regulatory Cooperation Project and its International Competition Policy Working Group.
} 


\section{$\underline{\text { Introduction }}$}

Ever since the creation of the General Court ("GC"), the effectiveness of judicial review in European Union ("EU") competition cases has sparked intense scholarly debates.

This paper seeks to further contribute to this discussion in three ways. ${ }^{1}$ First, it devotes some space to fundamental, yet often overlooked questions, such as the goals or functions of judicial review and why judicial review of administrative decisions is important; particularly so in competition law matters. Second, this paper attempts to throw some empirical light on the GC's judicial review of European Commission ("Commission") decisions in the field of competition law. Third, it places a specific emphasis on the particular situation of abuse of dominance law, where the GC has exercised its judicial review power with more restraint than in other areas of competition law (such as restrictive agreements and mergers).

With these goals in mind, this paper follows a five-stage progression. First, on the basis of a survey of the relevant legal, economic and political science literature, it defines the functions of judicial review and identifies a set of indicators which can be used to assess the performance of the GC's judicial scrutiny (Part I). Second, it explains why judicial review in EU competition law cases is of critical importance notably given the institutional and procedural deficiencies of the EU enforcement structure (Part II). Third, it discusses the nature and standard of review currently applied by the GC with a particular focus on the degree to which the GC is willing to review "complex economic matters" (Part III). Fourth, it provides some quantitative data on the case-law of the GC to assess whether several goals or functions attributed to judicial review by the scientific literature are met (Part IV).

Finally, this paper takes a closer look at the (controversial) case-law of the GC in the field of Article 102 of the Treaty on the Functioning of the European Union ("TFEU") (Part V). It observes that while the GC has taken initiatives to modernize normative legal standards in the fields of Article 101 of the Treaty on the Functioning of the European Union ("TFEU") and merger control, it has taken a conservative approach with respect to Article 102 TFEU where it has essentially relied on the formalistic case-law of the ECJ on exclusionary behaviour. In our view, this explains in large part why over the past decade, undertakings challenging Commission decisions have never been successful. The issue is not so much that the GC has turned a blind eye on the Commission's abuse of dominance position decisions (although it may also be part of the problem), but that the normative legal standards that are used to determine whether dominant firm conduct infringes Article 102 TFEU are so unfavorable to dominant firms and give so much discretion to the Commission that it is almost impossible for such firms to have infringement decisions overturned. Unless these standards evolve, there is a considerable risk that benign dominant firm conduct will be prohibited. These standards will also act as an impediment to economics- or effects-based oriented reforms, such as those initiated by the Commission in its Guidance Paper on Article 102 TFEU.

\section{The Functions of Judicial Review}

\section{A. The Case for a Functional Approach of Judicial Review}

\footnotetext{
${ }^{1}$ This paper does not deal with judicial review in State aid cases.
} 
Beyond the trite assertion that judicial review seeks to protect the "rule of law", European legal scholarship has offered scant guidance on the functions of judicial review. ${ }^{2}$ By contrast, other neighboring issues, such as the scope of judicial review, have exerted an almost "magnetic" attraction on European scholars. ${ }^{3}$ In reality, within the EU legal order, the utility of judicial review is often taken for granted. This may be due to the pervasive influence of legal positivism in continental Europe, which posits the existence of judicial review.

Our intention here is certainly not to suggest that judicial review is futile. Rather, the nub of our argument is that absent an accurate definition of the function(s) of judicial review - one which moves beyond the simple assertion that judicial review serves the "rule of law" there can be no rigorous assessment of the performance (or "effectiveness") of the judicial review mission exercised by the courts. ${ }^{4}$ In turn, absent a suitable measure of performance, there can be no informed discussion of related legal issues, such as the optimal intensity of judicial review, locus standi, the adequate appeal structure (i.e., ability to appeal a second time), etc. Those issues, which are of great importance to the practice of law, deserve the attention of EU legal scholars.

Given the dearth of scholarship on this issue within the EU, it is useful to consider United States ("US") legal doctrine. On the other side of the Atlantic, academic journals are replete with studies on the judicial review of congressional legislation by the Supreme Court. Since Marbury v. Madison, US scholars have shown a recurrent, some would say obsessive, ${ }^{5}$ interest in the possible inconsistency between judicial review and democracy. ${ }^{6}$ This scholarship provides interesting reflections on the "justifications for judicial review"." Moreover, besides judicial review of legislative action, US scholars have intensely debated the justifications for judicial review of decisions of administrative agencies (such as the Federal Trade Commission ("FTC") or the Federal Communications Commission ("FCC")). ${ }^{8}$ The following section relies on those works to elicit the various functions of judicial review.

\section{B. A Proposed Typology of the Functions of Judicial Review}

\footnotetext{
2 See Martin Shapiro, “Appeal”, (1980) 14 Law \& Society Review, pp. 629-661. With some limited exceptions, European legal scholars have left this issue untouched.

${ }^{3}$ See Oda Essens, Anna Gerbrandy and Saskia Lavrijssen (eds), National Courts and the Standard of Review in Competition Law and Economic Regulation, Groningen: Europa Law Publishing 2009; Jan S. Oster, "The Scope of Judicial Review in the German and U.S. Administrative System" (2008) 10 German Law Journal, pp. 12671296.

${ }^{4}$ See Jean Marc Sauvé, "Les critères de la qualité de la justice", in Célébration des vingt ans du Tribunal de première instance des Communautés européennes, Luxembourg le 25 septembre 2009.

${ }^{5}$ See David S. Law, “A Theory of Judicial Power and Judicial Review”, (2009) 97 Georgetown Law Journal, pp. $723-801$.

${ }^{6}$ See Alexander M. Bickel, The Least Dangerous Branch: The Supreme Court at the Bar of Politics, 2 nd ed. New Haven: Yale University Press, 1986. In brief, a large number of American scholars have challenged as illegitimate the Supreme Court's interference with majoritarian decisions taken by [democratically] elected institutions.

${ }^{7} \mathrm{See}$, for a good review of the literature, Alon Harel and Tsvi Kahana, "The Easy Core Case for Judicial Review", (2010) (2)1 Journal of Legal Analysis, pp. 227-256; D. Law, supra.

${ }^{8}$ See Stephen Breyer, Richard Stewart \& Cass Sunstein, Administrative Law and Regulatory Policy: Cases and Materials, $6^{\text {th }}$ ed., Aspen Publishing, 2006; Cass R. Sunstein, "On the Costs and Benefits of Aggressive Judicial Review of Agency Action", (1989) Duke Law Journal, pp.522-533; Louis L. Jaffe, “The Judicial Enforcement of Administrative Orders", (1963) 76(5) Harvard Law Review, pp. 865-928. Most papers, however, often fail to move beyond the blanket assertion that judicial review seeks to determine legality when there is a taking of life, liberty, or property.
} 
Lawyers, economists and political scientists assign three distinct functions to judicial review. First, lawyers conceive judicial review as a means to safeguard universal values (1). Second, economists consider that the function of judicial review is to promote economic welfare (2). Third, political scientists argue that judicial review purports to ensure accountability (3). Occasionally, scholars ascribe other functions to judicial review (4).

\section{Safeguarding Universal Values - The Lawyer's Standpoint}

According to legal scholars, judicial review primarily purports to protect non majoritarian values (e.g., fundamental rights, general principles of law, etc.). ${ }^{9}$ Because regulatory activity inevitably involves elected politicians/appointed bureaucrats supported by shifting majorities, ${ }^{10}$ the scrutiny of independent legal experts is deemed necessary to protect core substantive rights, principles and values.

This "rights-based" functional approach to judicial review has two variants. A first variant regards judicial review as a means of protecting the rights of minorities, notably in ensuring (i) participation in regulatory debates; and (ii) representativeness of regulatory choices. ${ }^{11}$ In practice, judicial review should thus primarily bear on the observance of fundamental procedural rights. For instance, when the Commission adopts regulations which harm a particular category of firms (for instance, brick and mortar firms in the field of vertical agreements or liner conferences in the field of maritime transport); imposes a remedy to a firm that harms third parties (as was, for instance, the case in Alrosa); ${ }^{12}$ or clears a merger concentration adverse to certain specific businesses, those firms should benefit from full and open access to the Court, and the Court should assure that these parties have effectively had an opportunity to participate in the decision-making process.

A second, non exclusive, variant perceives judicial review as a means to protect all fundamental values - not only essential procedural values, but also substantive ones - from cyclical majoritarian influence. The famous legal theorist Dworkin once summarized that view in saying that judicial review should seek to offer a "forum of principle". ${ }^{13}$ Those values are not only textual ones, but encompass all the underlying moral values of the law. ${ }^{14}$ They should be elicited by the judge through conventional techniques of statutory interpretation (textualism, theological interpretation, etc.). In the field of EU competition law, examples of such values include general principles of law (e.g., legal certainty, proportionality, etc.), but also fundamental substantive principles (e.g., the principle of free and undistorted competition, the hardcore nature of market partitioning agreements, etc.).

\section{Promoting Welfare - The Economist's Standpoint}

\footnotetext{
${ }^{9}$ In liberal democracies, this generally implies verifying that the applicant has not been subject to an arbitrary, capricious or mistaken decision. See Martin Shapiro, supra, p.1.

10 See John A. Ferejohn, Frances McCall Rosenbluth, and Charles R. Shipan, "Comparative Judicial Politics" (October 2004), mimeo, at 5.

11 See John Ely, Democracy and Distrust: A Theory of Judical Review, Cambridge MA: Harvard University Press, 1980. See also Alon Harel and Tsvi Kahana, supra, p. 233. Because the primary victims of majoritarian systems are minorities, [standing doctrines should be broadly interpreted, so that all private and natural persons shall have a right to voice grievance against a decision/have a hearing before a reviewing court (regardless of the costs of such a standing rule).

${ }^{12}$ See Commission Decision 2006/520/EC of 22 February 2006 relating to a proceeding pursuant to Article 82 of the EC Treaty and Article 54 of the EEA Agreement (Case COMP/B-2/38.381 - De Beers).

${ }^{13}$ See Ronald Dworkin, "The Forum of Principle”, (1981) 56 N.Y.U. L. Rev. 469, pp. 486-87.

${ }^{14}$ See Riccardo Guastini, "Théorie et ontologie du droit chez Dworkin", (1986) Droit et société, pp. 17-28.
} 
In contrast to the "rights-based" approach of lawyers, economists take an "outcomebased" perspective on judicial review. ${ }^{15}$ In their view, judicial review seeks to promote economic welfare through the elimination of decisional errors (2.1.) and the setting of normative standards (2.2.).

\subsection{Eradicate Decisional Errors}

Experts of decision-theory frameworks, such as Shavell, envision judicial review as a "means of error correction". ${ }^{16}$ Put simply, judicial review aims at correcting flawed decisions, which have adverse effects on economic welfare. ${ }^{17}$ In addition, judicial review acts as an incentives device on decision-makers, inducing them to craft welfare-enhancing decisions for fear of having these decisions struck down, with resulting negative consequences on their reputation, prestige, etc. ${ }^{18}$ Finally, judicial review is perceived as a cheap, efficient alternative to other error-correction mechanisms, such as increases of the regulator's resources, ex ante impact assessments, peer review mechanisms, advisory committees, etc. ${ }^{19}$

Interestingly, Ahlborn, Evans and Padilla have recently sought to apply Shavell's findings to the field of competition law. They argue that judicial review can greatly contribute to reducing the likelihood of Type I decisional errors (false convictions) in competition proceedings. Because Type I decisional errors are more likely and costly than Type II decisional errors (false acquittals) in competition cases, they support a strong appeal system in this field. ${ }^{20}$

Of course, the views expressed in the above-cited literature are not universally held. Some economists have attempted to formally invalidate Shavell's optimistic findings on the efficiency of judicial review. ${ }^{21}$ Other scholars have also stressed that courts may lack the information and expertise required to review regulatory decisions. ${ }^{22}$ Recently, two US academics put forward empirical evidence to the effect that complex antitrust cases might be

\footnotetext{
${ }_{15}$ Also labelled consequentialist approach.

${ }^{16}$ See Steven Shavell, "The Appeals Process as a Means of Error Correction”, (1995) 24 Journal of Legal Studies, pp. 379-426. See also, Andrew F. Daugherty and Jennifer F. Reinganum, “Appealing Judgments”, (2000) 31(3) Rand Journal of Economics, pp. 502-526.

${ }^{17}$ The appeals "market" leads to efficient doctrines, because there will be more - or only - appeals of inefficient, costly decisions by the parties. By contrast, efficient decisions will not be appealed by the parties. See George Priest, "The Common Law Process and the Selection of Efficient Doctrines", (1977) 6 Journal of Legal Studies, pp. 65-82; William Landes and Richard Posner, "Legal Precedent: A Theoretical and Empirical Analysis", (1976) 19 Journal of Law and Economics, pp. 249-307.

${ }^{18}$ See Richard Posner, "What do Judges and Justices Maximize? (the Same Thing Everybody Does)", (1993) 3 Supreme Court Economic Review, pp. 1-41. See also Steven Shavell who endorses this view supra p. 426.

${ }^{19}$ See Steven Shavell, supra.

${ }^{20}$ See Christian Ahlborn, David Evans and Jorge Padilla, "Unilateral Practices, Antitrust Rules and Judicial Review", mimeo.

${ }^{21}$ See Moshe Bar Niv and Zvi Safra, "On the Desirability of Appellate Courts" (2006) 2:3 Review of Law and Economics, pp. 381-396 (arguing that the suppression of appeals could lead to increase in total social welfare).

${ }^{22}$ See Matthew C. Stephenson and Justin Fox, "Judicial Review and Democratic Failure", (August 20, 2009). Harvard Public Law Working Paper No. 09-47.
} 
too complicated for generalist judges. ${ }^{23}$ Finally, scholars have voiced concerns over a risk of "ossification" of agency action arising from systematic annulments. ${ }^{24}$

Whilst detailed discussion of these studies is beyond the scope of this paper, we view as reasonable the baseline assumption that appeals help eradicate decisional errors.

\subsection{Establish Normative Standards}

A view that many economists promote is that judicial review fosters welfare through the definition of binding normative standards (or rule-making) ${ }^{25}$ First, the setting of a binding normative standard by a review court ensures downstream uniformity (Shavell talks of "harmonization"). ${ }^{26}$ From an economic standpoint, uniformity yields several positive effects. It limits transaction costs, leads to economies of scale, and eliminates negative legal externalities. In the field of EU competition law, where enforcement is decentralized, the definition of binding normative standards in Luxembourg has a positive harmonizing effect throughout the 27 Member States.

Second, when review courts affirm binding normative standards, they limit the ability of administrative agencies to promote regulatory changes in the future. ${ }^{27}$ Binding normative standards thus contribute to legal certainty in rendering the legal environment more durable and predictable. ${ }^{28}$ This, in turn, is often positively correlated to economic efficiency. ${ }^{29}$ Legal certainty limits compliance costs because firms do not need to monitor the regulator's activities on an ongoing basis.

That said, the adoption of binding normative standards has a number of shortcomings. First, binding normative standards may prevent regulatory experimentation and innovation at downstream levels. Second, in legal orders applying a strong doctrine of precedent - or, more prosaically, because of statu quo biases - obsolete normative standards (for instance, standards that do not reflect the evolution of science) may remain in force for unduly long periods of time. ${ }^{30}$ In this context, it has long been suggested that the case-law standards under Article 102 TFEU are no longer in line with state of the art competition economics.

\footnotetext{
${ }^{23}$ See Michael R. Baye and Joshua D. Wright, "Is Antitrust Too Complicated for Generalist Judges? The Impact of Economic Complexity \& Judicial Training on Appeals" (January 27, 2009), Journal of Law and Economics, pp. 1-37.

${ }^{24}$ See Matthew C. Stephenson and Justin Fox, supra, note 22

${ }^{25}$ In relation to agencies rulemaking activities. See Thomas O. McGarity, "Some Thoughts on "Deossifying" the Rulemaking Process", (1992) 41 Duke Law Journal, pp. 1385-1462.

${ }^{26}$ See Martin Shapiro, supra p. 629. But not necessarily, see Steven Shavell supra note 16

27 This argument is partly drawn from Andrew F. Hanssen, "Is There a Politically Optimal Level of Judicial Independence?” (2004) 94(3) American Economic Review, pp. 712-729

${ }^{28}$ This is true regardless of whether the affirmed standard involves a bright line rule or a vague notion. There is however a lively debate over the question of the content of standards in terms of legal certainty, with authors arguing that bright line, clear rules (such as per se presumptions, for instance), deliver less legal certainty than vague standards. See, Ofer Raban, "The Fallacy of Legal Certainty: Why Vague Legal Standards May be Better for Capitalism and Liberalism", Boston Univ. Public Int. L. J. (forthcoming).

${ }^{29}$ See Christophe Roquilly and Christophe Collard, La performance juridique: pour une vision stratégique du droit dans l'entreprise, LGDJ, 2010, §§27-29.

${ }^{30}$ See Emily Hammond Meazell, "Super Deference, the Science Obsession, and Judicial Review of Agency Science", (2010) 109 Michigan Law Review, forthcoming.
} 
Finally, binding normative standards only have positive economic effects if properly disseminated (to regulators and the public at large). This implies that courts should make it easy for ordinary readers to grasp the content of their decisions. ${ }^{31}$

\section{Ensuring Accountability - The Political Scientist's Standpoint}

Political scientists perceive judicial review as an instrument of "good governance". In essence, they conceive the relationship between elected governments and independent administrative agencies through the lenses of Principal-Agent theory. ${ }^{32}$ A government - the Principal - assigns regulatory duties and powers to an administrative agency - the Agent. ${ }^{33}$ This regulatory paradigm, which is predicated on the view that independent and expert decisions reach efficient outcomes, ${ }^{34}$ has been followed in a wide range of sectors (e.g., monetary issues, food safety, network industries, competition law, etc.).

The delegation of regulatory powers to independent bodies, however, gives rise to a risk of "democratic failure". ${ }^{5}$ Principal-Agent theory shows that under the veil of informational asymmetries, administrative agencies may pursue interests alien to the terms of the delegation (a situation described as a "moral hazard" problem). This risk stems from the facts that administrative agencies are prone to capture, ${ }^{36}$ political biases, ${ }^{37}$ behavioral failures, ${ }^{38}$ etc.

A key tenet of Principal-Agent theory is that moral hazard can be defused through control mechanisms. Accordingly, political scientists have made significant efforts to devise accountability instruments, which do not undermine the agencies' independence. Among these instruments, judicial review occupies a predominant place. Many political scientists consider that ex post judicial review is in general superior to other accountability instruments (e.g., political or managerial controls). ${ }^{39}$ More specifically, in political systems fraught with democratic deficit (such as the EU), ${ }^{40}$ judicial review enjoys a pivotal accountability function.

\footnotetext{
${ }^{31}$ See D. Law, supra note 5 p. 723.

${ }^{32}$ See D. Law, supra note 5; Dirk Lehmkul, "On Government, Governance and Judicial Review: the Case of European Union Competition Policy”, (2008) 28(1) Journal of Public Policy, pp.139-159.

${ }^{33}$ This may be compared to a theory of delegation.

${ }^{34}$ See Paul Magnette, "The Politics of Regulation in the European Union” in D. Geradin et al. (Eds.), Regulation through Agencies: A New Paradigm of European Governance, Edward Elgar, 2005, p. 6.

${ }^{35}$ See Matthew C. Stephenson and Justin Fox, supra.

${ }^{36}$ See George Stigler, "The Theory of Economic Regulation" (1971) 2 Bell Journal of Economic Management Science, pp. 3-21; Eric Maskin and Jean Tirole, "The Politician and the Judge: Accountability in Government", (2004) 94 American Economic Review, pp. 1034-1054. Majoritarian institutions - or regulatory institutions subject to political appointment - will promote populist short term measures which deviate from long term welfare. Judicial review is thus important to correct this, through the promotion of non-majoritarian rules which maximize long term welfare

${ }^{37}$ See Matthew L. Spitzer and Eric L. Talley, "Judicial Auditing” (June 1999), USC CLEO Research Paper No. 98-22.

${ }^{38}$ See Mark Seidenfeld, "The Psychology of Accountability and Political Review of Agency Rules", (2001) 51 Duke Law Journal, pp. 1059-1095.

39 See, however, Jerry L. Mashaw, "Judicial Review of Administrative Action: Reflections on Balancing Political, Managerial and Legal Accountability", (2005) Revista DIREITOGV 1(special issue 1), pp. 153-170. Yet, making officials accountable to courts enshrine a raft of contradictions: "it supports democratic governance by making officials accountable to unelected judges. It protects individual rights while simultaneously ensuring state control". See also JR DeShazo and Jody Freeman, "The Congressional Competition for Control of Delegated Power", UCLA, School of Law Research Paper No. 02-24.

${ }^{40}$ See Martin Shapiro, "The Institutionalization of European Administrative Space", (11-10-2004) Center for Culture, Organizations and Politics, Institute for Research on Labor and Employment, UC Berkeley, pp. 1-47.
} 
Other scholars have, however, warned that judicial review may aggravate democratic failures, just as regulatory intervention can exacerbate market failures. First, judges might also pursue selfish motives or be influenced by behavioral biases or other cognitive quirks. ${ }^{41}$ Second, the very existence of a judicial review system may change the incentives of administrative agencies and enhance moral hazard. Anticipating that regulatory mistakes can be subsequently rectified, administrative agencies subject to an ex post error correction mechanism may indeed be tempted to act carelessly.

In sum, whilst there seems to be a broad consensus that judicial review serves "good governance" purposes, political scientists remain divided over its effectiveness (in particular when compared to other accountability instruments). As far as competition law is concerned, the Commission's internal reforms of 2004 - which followed a string of annulment judgments - provide a practical illustration of the accountability dimension of judicial review.

\section{Other Functions of Judicial Review}

A whole host of other - albeit less fundamental - functions have been ascribed to judicial review, ${ }^{42}$ but this paper only considers the most salient of these. First, a functional theory justifies judicial review by the need to provide certain psychic benefits to addressees of regulatory decisions (such as catharsis, acceptance, etc.). ${ }^{43}$ Knowing that they can avail themselves of " $a$ day in court", addressees of decisions will tend to view regulatory interventions as more legitimate. Another function of judicial review may be to reach settlement over issues triggering disagreement (for instance, the interpretation of a particular provision). This function is critical to ensure social, legal and economic stability. ${ }^{44}$

\section{Importance of Judicial Review in EU Competition Law}

As seen in Part I of this paper, a system of judicial review of decisions adopted by administrative authorities fulfils several important functions. It is thus desirable to entitle natural and legal persons with the right to challenge decisions of administrative authorities, regardless of the field these authorities are entrusted to regulate.

With this in mind, this Part takes an epistemological perspective on judicial review. It discusses several general features of competition law (as a discipline) which render an effective system of judicial review particularly necessary in this field, despite possible concerns of decisional "ossification" (the limitation of the agency's margin of discretion) (Section A) ${ }^{45}$ It then focuses on EU competition law, and argues that the need for effective judicial review is further compounded by the institutional and procedural idiosyncrasies of the enforcement structure organized by the TFEU and secondary legislation (Section B).

\footnotetext{
The democratic deficit arises from a range of factors (absence of EU political parties, informational asymmetries which prevent direct citizenry control, absence of formal separation of power, politicization of EU Commission through multi-function portfolio, etc.).

${ }^{41}$ See Kent Curtis, "Judicial Review and Populism", (2003) 3 Wake Forest Law Review, pp. 313-74.

${ }^{42}$ Including innovative ones, such as e.g., providing an insurance policy against regulation.

${ }^{43}$ See Martin Shapiro, supra note 40, p. 630.

${ }^{44}$ See Alon Harel and Tsvi Kahana, supra note 7, p. 231.

${ }^{45}$ Our reference to competition law(s) covers statutory legislation, other regulatory instruments (regulations and soft law) and the case-law (judgments and decisions).
} 


\section{A. Importance of Judicial Review in Competition Law}

Several features of competition law make judicial review in this field particularly essential. First, competition law is prone to serious errors (1). Second, the enforcement of competition rules may seriously interferes with fundamental rights (2). Third, the delegation entrusted to a competition authority may not necessarily be exercised in the public interest (3).

\section{Competition Law is Prone to Serious Errors}

Lack of Conceptual Homogeneity - The successive development of antitrust schools of thoughts, such as the Harvard School, ${ }^{46}$ the Chicago School, ${ }^{47}$ and the post-Chicago School has created a significant degree of conceptual complexity. ${ }^{48}$ Modern competition law regimes are no longer anchored in a firm, unitary conceptual framework. Rather, they borrow influences from distinct, and sometimes contradictory, theories; rely on diverse assumptions; and apply heterogeneous evidentiary techniques. While theoretical diversity may be a source of richness, and avoid the pitfalls of relying on one-sided theories, it may also be a source of confusion, and thus of errors, both in terms of competition policy-making, but also in terms of adjudication. Competition authorities will often be confronted with a patchwork of inconsistent theories concocted by clever plaintiffs and defense counsel. ${ }^{49}$ This may lead to confused, and thus generally misguided, enforcement initiatives (type I errors). Conversely, this may lead to deficient enforcement, when the agency fails to take a decision for fear of selecting amongst alternative theories (type II errors).

This problem of intellectual confusion was nicely illustrated by FTC Commissioner Bill Kovacic in a recent paper, in which he claimed:

"In the most common form of the narrative, the Post-Chicago School offers the principal intellectual alternative to the Chicago School. The Post-Chicago literature generally defines a broader zone for antitrust intervention. One body of Post-Chicago commentary describes how, in some circumstances, exclusive dealing, tying, and other vertical restraints can facilitate the acquisition or maintenance of market power on grounds other than efficiency. Other Post-Chicago commentators have suggested how firms can use a mix of price and non-price strategies to diminish economic performance by deterring entry and expansion by rivals. Some Post-Chicago commentators accept the primacy of an efficiency framework, while others say that

\footnotetext{
${ }^{46}$ See Joe S. Bain, Industrial Organization, John Wiley \& Sons, New York, 1968; C. Kaysen and D. F. Turner Antitrust Policy, Harvard University Press, Cambridge, 1959.

${ }^{47}$ See Richard Posner, "The Chicago School of Antitrust Analysis", (1979) 127 University of Pennsylvania Law Review, pp. 925-943; Harold Demsetz, “Industry Structure, Market Rivalry and Public Policy”, (1973) 16 Journal of Law and Economics, pp. 1-9.

${ }^{48}$ The Post Chicago school of thought draws inspiration from the literature on "strategic firm behavior". Post Chicago scholars consider that a myriad of manifestly innocuous business conduct may be viewed as anticompetitive in specific conditions. This is certainly true of all the types of unilateral conduct caught under abuse of dominance/monopolization laws (rebates, discounts, technological integration), as well as of other types of coordinated conducts (vertical restraints, joint ventures, etc.). See Steven. C. Salop and David. T. Scheffman, "Cost-Raising Strategies", (1987) 36(1) Journal of Industrial Economics, pp. 19-34; Steven. C. Salop, "Strategic Entry Deterrence", (1979) 69 American Economic Review, pp. 335-338; Janusz A. Ordover and Robert D. Willig, "An Economic Definition of Predation: Pricing and Product Innovation", (1981) 91(1) The Yale Law Journal, pp. 8-53.

${ }^{49}$ The risks of over- or under-enforcement of antitrust rules was outlined in Frank Easterbrook's seminal article "The Limits of Antitrust", (1984) 63 Texas Law Review, 1.
} 
antitrust policy should serve distributional and other objectives. Post-Chicago observers generally express greater faith than do their Chicago School counterparts in the capacity of government institutions to make wise choices about when and how to intervene." 50

Evidentiary Hurdles - Enforcing competition rules is by no means easy. As in any discipline (econometrics, criminal law, etc.), which involves heavy reliance on ex post circumstantial evidence, competition law enforcers are routinely confronted with "identification" problems. ${ }^{51}$ For instance, no one will deny that there may be instances where it is particularly difficult to determine whether the growth of the market share of a dominant firm is due to abusive conduct (e.g., exclusionary pricing) or to the inefficiency of its rivals. Similarly, as in other disciplines where ex ante predictions must be formulated (macroeconomics, investment banking, etc.), competition enforcers face daunting "informational" difficulties, which generate a "speculation" problem. This risk is particularly significant in the area of merger control, where competition enforcers find it often difficult to determine the outcome of a proposed transaction on the competitive process.

Sophisticated Normative Standards - The demise of formalistic standards in favor of economic analysis (a development which we should all applaud) creates special challenges for competition enforcers. ${ }^{52}$ It is far easier for enforcers to decide that a given contract contains "fidelity rebates" and should therefore be per se illegal pursuant to the case law of the EU Courts ${ }^{53}$ than to reach the conclusion that such rebates create foreclosure effects on the basis of price-cost analysis. ${ }^{54}$ Of course, with the limited exception of price-fixing and other hard core cartels, the application of per se rules to common commercial practices is inadequate (as their "commonness", even in the absence of market power, clearly suggest the presence of efficiencies), but the application of economic-based standards raises its own difficulties. ${ }^{55}$

"Subject Matter" Complexity - Gone are the days where most competition cases concerned basic goods or industries. With the rise of information technologies over the past twenty years, the economy has stumbled into a constant adaptive process, and new, complex markets appear on a daily basis. This evolution generates a significant challenge for competition enforcers in terms of expertise, monitoring, and procedural efficiency, which may translate into increased risks of decisional errors.

Costs of errors - Antitrust experts may disagree over whether Type I errors are more frequent or harmful to consumer welfare than Type II errors or vice-versa. ${ }^{56}$ That said, there is

\footnotetext{
${ }^{50}$ See Bill Kovacic, "The Intellectual DNA of Modern U.S. Competition Law for Dominant Firm Conduct: The Chicago/Harvard Double Helix" (2007) 1 Columbia Business Law Review, pp. 1-80.

${ }^{51}$ To the exception of areas where infringements can be found on the basis of clear, undisputable evidence (e.g. cartels).

${ }^{52}$ See Fred McChesney, "Easterbrook on Errors", (2010) 6(1) Journal of Competition Law and Economics, pp. 11-31.

${ }^{53}$ For a discussion of the formalistic case-law of the EU courts in the area of rebates, see Denis Waelbroeck, "Michelin II: A Per Se Rule against Rebates by Dominant Companies?", (2005) 1 Journal of Competition Law and Economics, pp. 149-171.

${ }^{54}$ See Damien Geradin, "A Proposed Test for Separating Pro-competitive Conditional Rebates from Anticompetitive Ones" (2009) 32 World Competition, pp. 41-69.

${ }^{55}$ See Fred McChesney, supra note 52.

${ }^{56}$ See, for instance, Frank Easterbrook, supra note 49, at 2 for whom the cost of false positive is much higher than the costs of false negatives ("If the court errs by condemning a beneficial practice, the benefits may be lost for good. Any other firm that uses the condemned practice faces sanctions in the name of stare decisis, no matter
} 
consensus that the costs resulting from both types errors are serious. A first reason for this is that most modern competition laws provide for strict sanctions of an administrative or criminal nature. In a growing number of jurisdictions, cartelists can be sentenced to jail time or professional disqualifications. In others, competition law infringements are punished by increasingly severe fines. In the EU, for instance, fines have increased exponentially these last few years, ${ }^{57}$ including in non-cartel infringements, and in a recent case have passed the billion Euro mark. ${ }^{58}$ These fines, which have created concerns in the legal, corporate and political communities, ${ }^{59}$ tend to be much higher than the financial penalties imposed for other types of harmful corporate offences. For instance, on 9 September 2010, the Financial Times reported that Goldman Sachs was handed down "a large fine" of $£ 17.5$ millions by the UK Financial Services Authority (FSA) for failing to tell the regulator that it was the subject of a U.S. probe, an infringement described as of a serious nature. ${ }^{60}$ This fine, which appears very small considering the size of the infringer, is however the second highest fine ever imposed by the FSA. ${ }^{61}$

In addition, mistaken antitrust decisions often have serious adverse consequences on welfare. A decision wrongly banning pro-competitive discount or rebates (Type-I error), for instance, deprives consumers of lower prices and creates a price umbrella whose sole effect will be to protect inefficient competitors, ${ }^{62}$ and decisions mistakenly interfering with product design, by for instance preventing efficient forms of product integration or tying, deprive consumers from smaller, cheaper and more innovative products. What makes erroneous antitrust decisions particularly costly for society is that they do not only affect the recipient of the mistaken infringement decision, but a much larger group of market actors which, as result, may refrain from adopting the conduct prohibited by that decision. ${ }^{63}$ Similarly, in the case of Type-II errors, both competitors and/or consumers may suffer from the conduct that should

the benefits. If the court errs by permitting a deleterious practice, though, the welfare loss decreases over time. Monopoly is self-destructive. Monopoly prices eventually attract entry. True, this long run may be a long time coming, with loss to society in the interim. The central purpose of antitrust is to speed up the arrival of the long run. But this should not obscure the point: judicial errors that tolerate baleful practices are self-correcting, while erroneous condemnations are not.") Most competition authorities surely have a more nuanced view. See, e.g., Thomas Rosch, "Thoughts on the Withdrawal of the DOJ Section 2 Report", (25 June 2009) IBA/ABA Conference on Antitrust in a Global Economy, pp. 1-19 (criticizing the DoJ's Section II Report for downplaying "the risk of under-enforcement (Type II error), while emphasizing the risks of over-enforcement (Type I error).")

${ }^{57} \mathrm{See}$ "Enforcement by the Commission - The Decisional and Enforcement Structure in Antitrust Cases and the Commission's Fining System", Report presented at the Fifth Annual Conference of the Global Competition Law Center, 11-12 June 2009 (hereafter, the "GCLC Report").

${ }^{58}$ In its recent decision, the Commission imposed a fine of $€ 1.06$ billion on Intel on the ground that it adopted adopted exclusionary rebates contrary to Article 102 TFEU. See Commission Decision of 13 May 2009, COMP/37-990 Intel, available at http://ec.europa.eu/competition/sectors/ict/intel.html

${ }^{59} \mathrm{See}$, for instance, in France the report of Folz-Schaub-Raysseguier, Rapport sur l'appréciation de la sanction en matière de pratiques anticoncurrentielles, Septembre 2010.

${ }^{60}$ See "Goldman Swallows £17.5 Millions of Humble Pie”, Financial Times, 10 September 2010, 4.

${ }^{61} I d$. The biggest fine ever imposed by the FSA came in May 2010 when JP Morgan paid $£ 33.3$ millions for failing to keep clients money in separate accounts.

${ }^{62}$ See Damien Geradin, supra note 54.

${ }^{63}$ See Nicolas Forwood, "The Commission's More Economic Approach: Implications for the Role of the EU Courts, the Treatment of Economic Evidence and the Scope of Judicial Review", forthcoming in C.D. Ehlermann and Mel Marquis (Eds.), European Competition Law Annual 2009: Evaluation of Evidence and Its Judicial Review in Competition Cases, Hart Publishing, 2010 (“[...] competition law produces its effects principally through the many businesses who adapt their commercial behaviour so as to remain within the limits of what they perceive to be required by the law, rather than through the few whose conduct is subject to individual examination by regulator or court found to transgress the limits of legitimate commercial behaviour") 
have been prohibited. At worse, the victim of an infringement may simply be forced out of the market, with dramatic consequences for society at large.

Hence, because antitrust is prone to costly decisional mistakes, judicial review offers a crucially important opportunity to correct the adverse effects of misguided decisions on welfare. This goes to the core of the "outcome-based" approach to judicial review supported by economists.

\section{Competition Law interferes with Fundamental Rights}

In forbidding firms to trade freely in the market place, competition law seriously interferes with individual freedoms, such as for instance, the freedom of association, ${ }^{64}$ ownership of property, ${ }^{65}$ or the right to protection of personal data. ${ }^{66}$ In many countries, those rights are protected by constitutional texts. In addition, they may be protected by international instruments, such as the European Convention on Human Rights and Individual Freedoms (the "ECtHR").

The antagonism between competition law and individual freedoms becomes even clearer from a procedural standpoint. Competition authorities have typically the right to conduct inspections at the premises of undertakings that are suspected of anti-competitive conduct (as well as in many jurisdictions at the private homes of their executives) and to require documents (and explanations) relating to the subject matter of the investigation. ${ }^{67}$ In addition to carrying out inspections, competition authorities can also make extremely extensive requests for information resulting in most cases in the submission of (hundreds of) thousands of documents, including private correspondence. To ensure compliance, competition authorities can usually use coercive measures to obtain the information they need for their investigations, including the power to impose very serious fines ${ }^{68}$ or in some jurisdictions criminal penalties. ${ }^{69}$ Few other administrative authorities have such extensive investigative powers at their disposal and, among those who have such powers, few will exercise them with the same vigour and rigour as antitrust authorities.

In addition, competition authorities may adopt decisions that seriously encroach upon property rights. This is, for instance, the case when dominant firms on an upstream market are mandated to supply downstream competitors with essential inputs (e.g., access to infrastructures in cases involving network industries) ${ }^{70}$ or even to license their intellectual property rights (as ordered by the Commission in the Microsoft case). ${ }^{71}$ In some cases,

\footnotetext{
${ }^{64}$ Id. at Article 12

${ }^{65} \mathrm{Id}$. at Article 17

${ }^{66}$ See Article 8 of the European Convention on Human Rights and Individual Freedoms.

${ }^{67}$ See, e.g., Articles 17-21 of Council Regulation (EC) No 1/2003 of 16 December 2002 on the implementation of the rules on competition laid down in Articles 81 and 82 of the Treaty, (2003) O.J. L 1/1.

${ }^{68}$ See, e.g., Article 23(1) of Regulation 1/2003, op. cit.

${ }^{69}$ See Section 65 of the U.K. Competition Act.

${ }^{70}$ In EU competition law, the main cases are Cases 6 and 7-73, Commercial Solvents and Others v. Commission, [1974] ECR 223; C-7/97, Oscar Bronner v. Mediaprint, [1998] ECR I-7791. In US antitrust law, the main cases are United States v. Terminal Railroad Association, 224 U.S. 383 (1912); Aspen Skiing Co. v. Aspen Highlands Skiing Corp., 472 U.S. 585, 601 (1985); Verizon Communications Inc. v. Law Offices of Curtis V. Trinko, LLP 540 U.S. 682, (2004).

${ }^{71}$ See Commission Decision of 24 March 2004 (Case COMP/C-3/37.792 Microsoft), C(2004)900 final. For the relevant case-law, see cases C-241/91 and C-242/91, Radio Telefis Eireann and Independent Television Publications Ltd v. Commission, [1995] ECR 743; Case C-418/01, IMS Health GmbH \& Co. OHG v. NDC
} 
competition decisions can be said to amount to "regulatory takings" when they force a company to divest some of its property as part of a remedy to an antitrust infringement or in order to obtain prior approval for a transaction ("structural remedies"); ${ }^{72}$ or when they extensively regulate the way a company can use its property rights ("behavioural" remedies).

In other words, competition law investigations and decisions may be extremely intrusive, and thus need to be subject to review to ensure that basic rights of the subject of competition law are protected and that abuses of power are redressed. This goes to the "rights-based" approach of judicial review described in Part I.

\section{Competition Law may not be enforced in the Public Interest}

Competition laws are not enforced by disincarnate institutions. Rather, the enforcement delegation vested in expert authorities is implemented through a series of subdelegations to individual officials. This, in turn, creates a subset of Principal-Agent problems. As Wouter Wils, a long-time member of the Commission's Legal Service and the newly appointed Hearing Officer, observed several years ago in an excellent paper, officials in charge of competition enforcement may - as other officials - be subject to a variety of biases. ${ }^{73}$ First, there is perhaps a natural, psychological inclination for an official entrusted with investigative duties to search for and give greater weight to evidence that support his belief that an infringement has occurred. ${ }^{74}$ This "confirmation bias" creates the risk that evidence that does not neatly fit with the theory of harm a case team seeks to prove will be consciously or, more likely, unconsciously ignored or given less importance. ${ }^{75}$ This problem, as is well known, was a bone of contention between Intel and the Commission during the latter's investigation of Intel's rebates to OEMs. ${ }^{76}$

Second, in a world where performance standards are pervasive - including in large public administrations - competition officials may tend to be "results oriented", 77 hence

Health GmbH \& Co. KG, [2004] ECR 5039; See on this Damien Geradin, "Limiting the Scope of Article 82 of the EC Treaty: What can the EU Learn from the US Supreme Court's Judgment in Trinko in the wake of Microsoft, IMS, and Deutsche Telekom", (2004) 41 Common Market Law Review pp. 1519-1553.

${ }^{72}$ Article 7 of Regulation 1/2003 provides that "Where the Commission, acting on a complaint or on its own initiative, finds that there is an infringement of Article 81 or of Article 82 of the Treaty, it may by decision require the undertakings and associations of undertakings concerned to bring such infringement to an end. For this purpose, it may impose on them any behavioural or structural remedies which are proportionate to the infringement committed and necessary to bring the infringement effectively to an end." (emphasis added).

${ }^{73}$ See Wouter Wils, "The Combination of the Investigative and Prosecutorial Function and the Adjudicative Function in EC Antitrust Enforcement: A Legal and Economic Analysis", (2004) 27 World Competition, pp. 202-224

${ }^{74}$ See, e.g., Frank Montag, "The Case for Radical Reform of the Infringement Procedure under Regulation 17", (1996) 17 (8) European Competition Law Review, pp. 428-437, at p. 430 (claiming that it "is understandable in human terms that Commission officials sometimes want to push through what they perceive to be 'their' case. And it explains why arguments put forward by the parties often appear to fall on deaf ears."); Ian Forrester, "Due Process in EC Competition Cases: A Distinguished Institution with Flawed Procedures", (2009) 34 European Law Review pp. 817-843, at p. 841.

${ }^{75}$ See Wouter Wils, supra note 73.

${ }^{76}$ See Damien Geradin, "The Decision of the Commission of 13 May 2009 in the Intel case: Where is the Foreclosure and Consumer Harm?”, (2010) 1 Journal of European Competition Law \& Practice, 112.

${ }^{77}$ See Wouter Wils, supra note 73 (combination), (“Assuming that the European Commission's task with regard to the enforcement of Articles 81 and 82 is to create deterrence by detecting and adequately punishing a sufficient number of violations, with priority being given to the most harmful, one should expect the Commission, the Competition Commissioner and DG Competition to want to show to the outside world that they are fulfilling 
leading to a pro-enforcement bias. We are clearly not suggesting that antitrust officials are dishonest or unprofessional, which they are not, but their structure of incentives will often be such that they derive greater "value" from the adoption of an infringement decision than, for instance, a decision to discontinue an investigation. ${ }^{78}$ The natural inclination of antitrust officials is thus to push their case through the system. This is especially the case when officials have invested several months, or more often years, of their professional life in a given case, which they do not want to be "wasted" in a case dismissal. After a long and painful investigation, it may be understandably hard for an official to terminate an investigation even if the case for intervention is considerably weaker than initially envisaged. ${ }^{79}$ There is nothing particularly shocking about these observations as biases are part of human nature and, perhaps regrettably, affect every profession. ${ }^{80}$

However, from a public policy standpoint, the negative impact of such inevitable biases is that the competition laws might occasionally be enforced out of self interest, rather than in the public interest. Of course, such failures can be contained through the adoption of "checks and balances" (see Section B.2 below). However, when they are insufficient, manifestations of such biases should be corrected through judicial review of infringement decisions. ${ }^{81}$ This fits well with the promotion of "good governance" function of judicial review, which is highly valued by political scientists.

\section{B. Importance of Judicial Review in EU competition law}

In this section, we refocus our discussion on the enforcement structure of EU competition law decisions, and explain why judicial review of competition law decisions is particularly important. This is the case for three reasons. First, the institutional and procedural frameworks articulating the enforcement powers of the Commission are, as many observers would recognize, inadequate. Second, the vast enforcement powers entrusted to the Commission are not subject to sufficient checks and balances. Finally, the decisions of the Commission constitute a critical reference point for national competition authorities ("NCAs") and national courts of EU Member States.

\section{Inadequate Enforcement Structure}

One recurrent criticism about the current enforcement structure of is that the Commission combines investigative and decision-making functions. ${ }^{82}$ While this situation

this task well. One should thus not be surprised to observe that statistics of the number of decisions imposing fines and the amounts of these fines are being published.")

${ }^{78}$ Id. ("Similarly, to further their career and to earn the respect of their colleagues and friends, officials with DG Competition will want to show the contribution that they or their organizational division is making to fulfilling that task.")

${ }^{79}$ See Forrester, supra note 74 ("When diligent and honest officials investigate a case over a period of time, say four years, and then issue a statement of objections once the case is, say, 80 percent concluded, it is fully understandable that officials are reluctant to be persuaded that they were wrong. This problem of intellectual capture' of the Commission services is perhaps more serious.")

${ }^{80}$ For instance, within investigated companies, tensions may occur between the Office of the General Counsel and the Government Affairs (GA) Department. While the natural inclination of GA executives will be to run an active media campaign, in-house lawyers will generally been more cautious. Surely, both GA executives and lawyers want to win the case, but their structure of incentives may be different.

${ }^{81}$ See Wouter Wils, supra note 73 (combination) ("It is undeniable that the possibility of judicial review significantly reduces any risk of prosecutorial bias").

${ }^{82}$ See the GCLC Report, supra note 57; Ian Forrester, supra note 74. 
may not be unique to the European Commission, there are many who doubt that it represents best international practice. ${ }^{83}$ In the Member States, a clear separation is often made between investigative and adjudicatory functions. ${ }^{84}$ Competition authorities typically comprise two distinct bodies: a body that carries out the investigation and another body which takes the decision. ${ }^{85}$ Such a separation is certainly healthy in that it tends to avoid, or at least reduce, the risks of biases outlined in the prior section. It also grants the opportunity to the investigated firm to convince the decision-making body that the conclusions reached by the investigative body are flawed.

As a result, a scholarly debate has emerged as to whether the EU enforcement system corresponded to the standards established by the ECtHR,${ }^{86}$ in particular given the criminal or quasi-criminal nature of the fines imposed by the Commission. ${ }^{87}$ While we do not want to enter into this complex debate, it is sufficient to say that given the extreme severity of the fines, it is not unreasonable for undertakings subject to a Commission investigation to expect the guarantees offered by Article 6 of the ECHR, according to which " $[i] n$ the determination of his civil rights and obligations or of any criminal charge against him, everyone is entitled to a fair and public hearing within a reasonable time by an independent and impartial tribunal established by law." Given its investigative role, the Commission hardly qualifies as an "independent and impartial" tribunal within the meaning of that provision, although Wouter Wils argues this does not make the EU enforcement system contrary to Article 6 ECHR. The reason is that:

"the European Court of Human Rights has ruled that, for reasons of efficiency, the determination of civil rights and obligations and obligations or the prosecution and punishment of offences which are 'criminal' within the wider meaning of Article 6 ECHR can be entrusted to administrative authorities, provided that the persons concerned are able to challenge any decision thus made before a judicial body that has full jurisdiction and that provides full guarantees of Article 6(1) ECHR." 88

Whether or not one agrees with Mr. Wils' interpretation of the European Court of Human Right's case law, the above quote makes an important point, which is that for the EU antitrust enforcement system to be compatible with Article 6 ECHR, the decisions of the Commission have to be challengeable before a judicial body that has "full jurisdiction". Whether this condition is met will be discussed below in Part III.

\footnotetext{
${ }^{83}$ The EU enforcement structure is often compared with the US enforcement structure, which involves two distinct bodies: the Antitrust Division of the Department of Justice ("DoJ") and the Federal Trade Commission ("FTC"). While the DoJ holds extensive investigation powers, it does not have the ability to adopt infringement decisions and adopt sanctions. If the DoJ wants to bring an infringement to an end and the imposition of sanctions, it has to bring a case in a federal district court. The FTC does combine prosecutorial and adjudicative functions, but a stronger system of "checks and balances", including the intervention of an Administrative Law Judge, is part of the procedure. For a good comparison of the EU and the US Enforcement systems, see Wouter Wils, supra note 73 (combination).

${ }^{84}$ See GCLC Report, supra note 57.

${ }^{85}$ See Donald Slater, "Competition Law Proceedings before the European Commission and the Right to a Fair Trial: No Need for Reform”, GCLC Working Paper 04/08, at p. 39.

${ }^{86}$ See GCLC Report, supra note 57 and Ian Forrester, supra note 74 (claiming that the standards of the ECHR were not met). But see Wouter Wils, "The Increased Level of EU Antitrust Fines, Judicial Review, and the European Convention on Human Rights”, (2010) 33 World Competition, forthcoming.

${ }^{87} I$ d.

${ }^{88}$ See Wouter Wils, supra note 73 (combination).
} 
Another frequent criticism made by scholars and practitioners with respect to the EU enforcement system relates to the oral hearing provided for at Article 12 of Regulation $773 / 2004,{ }^{89}$ which investigated companies may request the benefit of once they have responded to a statement of objections sent by the Commission. This hearing process contains some defects. First, the hearing does not take place before the ultimate decision-makers, i.e. the College of Commissioners. ${ }^{90}$ The hearing will be attended by the case team and other Commission officials, such as members of the Legal Service or of other Directorates. ${ }^{91}$ However, the Competition Commissioner and the other members of the College of Commissioners will not be present. In addition, in the authors' experience, the Director General of DG Competition and other senior members of the management rarely attend. The investigated company is thus given an opportunity to challenge the evidence presented by the Commission in front of the very case team that collected that evidence and used it to write a statement of objections. While the Hearing Officer, a senior official who reports directly to the Commissioner, will ensure that the hearing is conducted in an appropriate manner and the procedural rights of the parties are respected, he has no ability to decide on the substance of the case. ${ }^{92}$

In sum, as pointed out by one of the deans of the Brussels competition bar, the Commission is certainly a "talented and prestigious institution", but it "is weakened by unique, and uniquely unsatisfactory, processes and procedures." 93 of course, this observation, which may seem harsh, is not targeted at DG Competition officials personally, but at the failure of the European Union to correct procedures, which though they may have appeared satisfactory when Regulation 17/62 was adopted almost fifty years ago, ${ }^{94}$ may no longer represent best international practice. This is not to say that no efforts have been made to improve the enforcement process through the adoption of checks and balances which, interestingly enough for the purpose of this paper, were introduced as a reaction to the shock created by the striking down by the General Court of a series of merger decisions. ${ }^{95}$ But, as we show in the next section, these laudable efforts are not sufficient.

\section{Insufficient Checks and Balances}

\footnotetext{
${ }^{89}$ Commission Regulation (EC) No 773/2004 of April 72004 relating to the conduct by the Commission pursuant to Articles 81 and 82 of the EC Treaty, OJ L 123, 27.4.2004, 18. Although less frequent than in antitrust proceedings, Article 14 of Commission Regulation (EC) No 802/2004 of 7 April 2004 implementing Council Regulation (EC) No 139/2004 on the control of concentrations between undertakings, OJ L 133, 30.4.2004, 1 grants parties the right to a hearing in Commission merger control proceedings.

${ }^{90}$ Infringement decisions are drafted are normally drafted by the DG Competition officials who investigated the case and drafted the statement of objections. They are adopted by majority vote by the Commission (i.e., the College of Commissioners), on a proposal of the Competition Commissioner, following consultation with the Legal Service and other Commission services and the Advisory Committee, which is made up of officials from the Member States.

${ }^{91}$ See Wouter Wils, supra note 73 (combination).

${ }^{92}$ Although the Hearing Officer will make comments on the substance of the case in his interim report (an internal Commission document that is not available to the parties).

${ }^{93}$ See Ian Forrester, supra note 74, 819.

${ }^{94}$ Regulation No 17: First Regulation implementing Articles 85 and 86 of the Treaty English special edition: Series I Chapter 1959-1962, p. 87

${ }^{95}$ See Mario Monti, "Merger control in the European Union : a radical reform European Commission/IBA Conference on EU Merger Control Brussels", 7 November 2002, SPEECH/02/545, available at http://europa.eu/rapid/pressReleasesAction.do?reference=SPEECH/02/545\&format=HTML\&aged=0\&language $=$ EN\&guiLanguage $=$ en
} 
Checks and balances should be part of every legal regime that can lead to the adoption of decisions with adverse effects on individuals (or groups of individuals). In most antitrust regimes, such checks and balances are ensured through the separation of the investigative and decision-making functions as the decision-maker will control the quality of the evidence and the strength of the case that has been put together by the investigating body. Such a separation does not exist under Regulation 1/2003.

In recent years, the Commission has, however, put into place a number of mechanisms designed to ensure some form of quality control on the work performed by case teams. First, the Commission created a Chief Economist position with the view to improve the quality of the economic reasoning contained in Commission decisions. ${ }^{96}$ That initiative was applauded by both scholars and practitioners. In the authors' experience, the CET, which is now composed of about twenty $\mathrm{PhD}$ economists, has also shown independence in that it has expressed, on a number of occasions, disagreement with the theories of harm developed by case teams. The (degree of) involvement of the CET, however, varies depending on the cases and the CET has no ability to block the issuance a statement of objections and eventual adoption of an infringement decision even if it disagrees with the theories of harm developed by the case team. In addition, as "intellectually" independent he may be, the Chief Economist is part of the DG Competition hierarchy and reports to the Director General.

Second, the Commission developed the so-called "devils' advocate" panels to review the strength of the case developed by the case team. ${ }^{97}$ These panels, which are composed of three officials of units that have not been involved in the investigation, play a useful role in that they provide a second opinion on whether the Commission should proceed with a given case. ${ }^{98}$ The setting up of these panels does not, however occur as a matter of course and, although it is the authors' understanding that panel members usually perform a good and thorough scrutiny of the case file, their independence is not guaranteed since these officials, as the Chief Economist, belong to DG Competition. In any event, their role is only advisory. Their opinion does not bind the DG Competition hierarchy.

Finally, the Intel investigation has also thrown the spotlight on the role that can be played by the European Ombudsman in competition cases. Following a complaint lodged by Intel, the Ombudsman adopted on 14 July 2009 a decision concluding that the Commission's failure to record and preserve the evidence produced at a meeting it held with a senior Dell executive in 2006 amounted to maladministration on the part of the Commission. ${ }^{99}$ This is of course a rather troubling finding, which the General Court will certainly look at when examining Intel's appeal to the Commission decision finding that it has violated Article 102 TFEU. The Ombudsman decisions do not, however, have binding effect, which is a significant limitation.

In sum, the measures taken by the Commission to improve its enforcement processes only provide a feeble check against the institutional and procedural lacunae that were

\footnotetext{
96 See Lars-Hendrik Röller and Pierre A. Buigues, "The Office of the Chief Competition Economist at the European Commission”, May 2005 available at http://ec.europa.eu/dgs/competition/officechiefecon ec.pdf

${ }^{97}$ See Mario Monti, supra note 95.

${ }^{98}$ On the scope of intervention of the panels, see Wouter Wils, supra note (combination) at 73 ("As a rule, the peer review takes place before the sending of Statement of Objections is decided, normally in all cases applying Article 82 EC and, where appropriate, also in cases applying Article 81 EC, but in principle not in cartel cases.")

${ }^{99}$ See Charles Forelle, "EU Draws Rebuke in Intel Case Lapse”, 9 August 2009, Wall Street Journal.
} 
identified above. Such measures, which remain wholly advisory in nature, cannot be compared with a comprehensive system of "checks and balances" which, as constitutional theory shows, involves the possibility to block the decision making process. With the limited exception of the intervention of the Legal Service, none of this is present in the EU competition enforcement structure. In addition, those mechanisms are activated discretionarily and, thus, do not apply in all cases.

\section{The influence of Commission Decisions at the National Level}

Commission decisions can have significant consequences for firms that are found to have committed an infringement of EU competition law, as well as for society as a whole. But these decisions are also a reference point for NCAs and national courts, in the course of their daily enforcement activities. EU Competition law is indeed directly applicable and extensively applied in the Member States. Mistaken decisions may thus reverberate throughout the EU, and have a snowball effect on NCAs and national courts.

In addition, as the guardian of the interpretation of EU law, the Court of Justice exercises an important harmonization function, which as has been observed in Part I is one of the key functions attributed to judicial review.

\section{Nature and Scope of Judicial Review in EU Competition Law}

In light of the above, it should not come as a surprise that most modern competition law regimes provide for some form of judicial review of the decisions adopted by the bodies (usually, specialized competition authorities) in charge of enforcing competition rules. This said, there are considerable discrepancies amongst jurisdictions in relation to the nature and scope of judicial review. In this respect, the TFEU provides for a specific system of judicial review which draws inspiration from the legal tradition of its founding Member States, and which applies to all areas of EU law (Section A). Whilst the Treaty provisions provide little guidance on the scope of judicial review, the EU Courts' case-law casts light on the intensity of judicial review in competition law matters (Section B).

\section{A. The Provisions of the TFEU}

The EU Courts' jurisdiction to review the decisions of the Commission in the field of EU competition law derives from the TFEU. Specifically, Article 263 TFEU provides that the European Court of Justice has jurisdiction over actions brought against Commission decisions:

"on grounds of lack of competence, infringement of an essential procedural requirement, infringement of the Treaties or of any rule of law relating to their application, or misuse of powers."

Article 261 TFEU provides that regulations adopted jointly by the European Parliament and the Council, pursuant to the provisions of the Treaties:

"may give the Court of Justice of the European Union unlimited jurisdiction with regard to the penalties provided for in such regulations." 
The fact that the EU Courts enjoy restricted rather than unlimited jurisdiction over Commission decisions (with the exception of the EU Courts' unlimited jurisdiction to review fines) means that the EU Courts are only entitled to review the legality of such decisions and when these decisions are illegal to annul them, rather than re-examine the case on the merits. $^{100}$

This results from the "institutional balance" put into place by the TFEU. ${ }^{101}$ While the Commission is entrusted with the enforcement of the competition law provisions contained in the TFEU and EU legislation, as well as the development of the EU competition policy, the EU Courts are given the task of reviewing the legality of the Commission decisions enforcing EU competition law. In practice, this means that the EU Courts are not entitled - as in a classic appeals procedure - to substitute their point of view for that of the Commission and adopt a de novo decision. When the EU Courts find a decision illegal, they must strike it down (in full or in part). ${ }^{102}$

\section{B. Full vs. Restrained Review of Commission Decisions}

As a consequence of the "institutional balance" described in the preceding section, the EU Courts have also recognized a "margin of discretion" to the Commission when reviewing "complex economic matters". As pointed out by former President of the General Court Bo Vesterdorf:

"[t]he intensity of control [exercised by the EU Courts over Commission decisions] varies depending on whether the Courts are reviewing, on the one hand, the correctness of the facts or the correct application of the law (full control) and, on the other hand, the correctness of the Commission's appreciation of complex economic matters (restrained control)." 103

While this distinction between the degree or the intensity of the control applied to issues of facts and law, and to complex economic matters is well accepted, it nevertheless raises some challenges. First, it is often hard to distinguish between issues of facts and law, and economic appreciations. Second, it is not clear how one should distinguish between "complex" and "non-complex" economic appreciations. These issues are dealt with in the developments that follow.

1. Review of the Law

The EU Courts exercise full scrutiny over the interpretation of EU competition law. The Commission enjoys no margin of discretion when it comes to the interpretation of EU

\footnotetext{
100 See Bo Vesterdorf, “Judicial Review in EC Competition Law: Reflections on the Role of the Community Courts in the EC System of Competition Law Enforcement", (2005) 1 Global Competition Policy 1, pp. 3-27, at p. 9 et seq.; David Bailey, "Scope of Judicial Review under Article 81 EC", (2004) 41 Common Market Law Review pp. 1327-1360, at p. 1330 et seq.

${ }^{101}$ See Bo Vesterdorf, supra note 100, at p. 10 ("The [EU] system envisaged a sort of institutional balance. The Commission and the Courts should focus on their respective primary functions: competition policy and enforcement on the one hand, judicial review on the other. It is a simple, but fundamentally important, premise which is enshrined in the EC Treaty itself.")

102 Only if the illegality is such that the decision would have been different absent it.

${ }^{103}$ See Bo Vesterdorf, supra note 100, at p. 11.
} 
law. ${ }^{104}$ It is for the EU Courts to interpret the law and verify whether the Commission has complied with their interpretation of the law when enforcing EU competition rules.

In this respect, the EU courts have developed legal standards both with respect to the procedural and substantive aspects of competition law. As far as procedural aspects are concerned, the EU Courts have emphasized the importance that the Commission respects the "rights of defense" in its enforcement of competition law. In a significant number of cases, the EU Courts have sought to ensure the strict observance of procedural rights by the Commission in its Articles 101 and 102 investigations, ${ }^{105}$ as well as in its merger control decisions. $^{106}$

As far as substantive aspects are concerned, the EU Courts have developed in their case-law a variety of legal standards (or tests) that should be relied upon to determine the compatibility with EU competition law of a wide range of commercial practices susceptible of creating anti-competitive effects, including horizontal agreements, vertical agreements, oligopolistic behaviour, exclusive dealing, rebates, predatory pricing, selective price cuts, tying and bundling, refusal to supply, margin squeeze, price discrimination, and exploitative prices and conditions. ${ }^{107}$

An important observation with respect to these legal tests is that they are intensely "economic" in nature. Questions, such as whether evidence of "recoupment" should be brought to determine whether the prices of a dominant firm are predatory or whether such a test should rely on a given cost benchmark rather than another, cannot be detached for the economics of exclusionary pricing. By adopting or refining such tests, the EU courts issue decisions of considerable economic importance for suppliers, their customers and end users. Because of their impact on welfare, such questions also involve economic policy choices. This shows that in competition law legal and economic questions cannot be seriously divorced as the content of the standards adopted by the EU courts translate economic reasoning and need to be implemented through economic tools.

\section{Review of the Facts}

Appraisal of the facts is critical in competition law matters as the vast majority of competition cases are won or lost on the facts rather than on abstract legal or economic theories. The critical importance of controlling the facts was one of the reasons that led to the creation of the "Court of First Instance" in 1989, now relabeled "General Court". ${ }^{108}$ This newly created Court took this mission very seriously. In the Italian Flat Glass case, the General Court stated that

"it is incumbent on it [...] to check meticulously the nature and import of the evidence taken into consideration by the Commission in the decision." 109

\footnotetext{
${ }^{104} I d .$, at p. 12.

105 See, e.g., Case C-374/87, Orkem v. Commission, [1989] ECR 3343, §§35-40 (holding that the Commission cannot use requests for information to force investigated firms to admit they have breached EU competition law); Case 155/79, AM\&S v. Commission, [1982] ECR 1575.

106 [TBC]

107 For a discussion of these standards, see Einer Elhauge and Damien Geradin, Global Antitrust Law \& Economics, Foundation Press, 2007.

${ }^{108}$ See Bo Vesterdorf, supra note 100 , at p. 13.

${ }^{109}$ Joined Cases T-68/89, T-77/82 and T-78/89, SIV v. Commission, [1992] ECR II-1403, §95.
} 
As a result, many judgments of the General Court dissect in the most minute details Commission decisions, and the Commission's inadequate treatment of the facts has led to the annulment of a significant number of Commission decisions both in the field of anticompetitive agreements and mergers. ${ }^{110}$

Of course, it is not always easy to determine whether a ground of appeal lodged by an undertaking challenging a Commission decision raises a question of facts, law or a matter of complex economic appraisal. Surely, primary or basic facts, such as whether a given meeting took place, the parties who attended the meeting, what was decided at that meeting, and whether the decisions taken at the meeting were subsequently implemented by the participants, raise no difficulty of categorization. The correctness of such facts, which are often determinative of the outcome of a case, are not a matter of economic appreciation and should thus be subject to the full control of the EU Courts.

Yet, the distinction becomes less clear when EU courts are confronted with what former Judge Sir David Edward refers to as "facts of an economic nature". ${ }^{111}$ For instance, a firm challenging a Commission decision finding that it has committed an abuse of dominance may argue that the Commission's definition of the relevant market is flawed, that it does not hold a dominant position and that its price or non-price related conduct does not amount to an abuse of dominance. Market definition issues clearly raise factual questions, such as whether Product A is a substitute to Product B. But they can also be framed as a legal question, such as whether the test used by the Commission is in line with the case-law of the EU Courts. In addition, market definition may also raise complex economic questions in particular as the Commission relies on economic tools to assess whether distinct products belong to the same market. ${ }^{112}$

That said, whether a ground of appeal raises factual and/or legal questions is of little practical significance since EU Courts can comprehensively review issues of facts and law. In contrast, the issue of whether the ground in question relates to matter of complex economic appraisals is important as it may determine the intensity of the review that may be exercised by the EU Court.

\section{Review of "Complex Economic Matters"}

The application of a deferential standard of review to complex economic matters is not a recent phenomenon. Such a standard was already applied by the Court of Justice in its seminal Consten v. Grunding judgment, where it held that:

"judicial review of complex economic evaluations by the Commission concerning [Article 101(3)] exemptions must take account of their nature by confining itself to an examination of the relevance of the facts and legal circumstances which the

\footnotetext{
${ }^{110}$ In the Airtours, Tetra Laval and Schneider/Legrand cases. See Cases Airtours v. Commission, [2002] ECR II02585; Tetra Laval v. Commission, [2002] ECR II-04519; and Schneider v. Commission, [2002] ECR II-04519. The General Court took issue with the lack of cogent and cogent evidence supporting the assertions made by the Commission.

111 See Christopher Bellamy, OECD Roundtable, Judicial Enforcement of Competition Law, 1996, p. 106 available at http://www.ecd.org/dataoecd/34/41/1919985.pdf

${ }^{112}$ See the various tools referred to in the Commission Notice on the definition of relevant market for the purposes of Community competition law, 1997 OJ C 372/5.
} 
Commission deduces therefrom. This review must in the first place be carried in respect of the reasons given for the decisions which must set out the facts and considerations on which the said evaluations are based."113

This standard of review, which the Court of Justice subsequently extended to evaluations made by the Commission regarding the application of Article 101(1) TFEU, ${ }^{114}$ has also been applied in cases involving the application of Article 102 TFEU and the Merger Control Regulation. In Microsoft, for instance, the General Court observed that it followed

"from consistent case-law that, although as a general rule the Community Courts undertake a comprehensive review of the question as to whether or not the conditions for the application of the competition rules are met, their review of complex economic appraisals made by the Commission is necessarily limited to checking whether the relevant rules on procedure and on stating reasons have been complied with, whether the facts have been accurately stated and whether there has been any manifest error of assessment or a misuse of powers."115

Similarly, in its Kali und Salz judgment, ${ }^{116}$ which concerned an appeal against a Commission decision, which stated that, as a result of a proposed concentration, two entities would enjoy a collective dominant position, the Court of Justice held that:

"the basic provisions of the [Merger Control] Regulation, in particular Article 2 thereof, confer on the Commission a certain discretion, especially with respect to assessments of an economic nature.

Consequently, review by the Community judicature of the exercise of that discretion, which is essential for defining the rules on concentrations, must take account of the discretionary margin implicit in the provisions of an economic nature which form part of the rules on concentrations."

The central question is of course to determine the content and contours of the notion of "complex economic matters". This question is critically important. First, as noted above, whether a contested item in a Commission decision is labeled as a question of " $f a c t$ " or an "economic issue" and, if the latter, whether this issue is "complex" determines the intensity of the review that should be carried out by the Commission. ${ }^{118}$ Second, as the Commission is increasingly applying a more "economic approach" to competition cases, unless the deferential standard of review applied to complex economic matters is carefully circumscribed, the review of its decisions could become increasingly "light" on the ground that the appraisal of complex economic issues should be the province of the Commission. ${ }^{119}$

\footnotetext{
${ }_{113}^{11}$ Cases C-56/64 \& 58/64, Etablissements Consten SaRL and Grunding-Verkaufs-GmbH, [1966] ECR 299.

${ }_{114}^{11}$ CaseC- 42/84, Remia v. Commission, [1996] ECR II-649.

115 Case T-201/04, Microsoft v. Commission, [2007] ECR II-3601, §87.

${ }^{116}$ Joined Cases C-68/94 and C-30/95, France et al. v. Commission (“Kali \& Salz”), [1998] ECR I-1375.

${ }^{117} \mathrm{Id}$. .

${ }^{118}$ See supra text accompanying notes

119 See Ian Forrester, "A Bush in Need of Pruning: The Luxuriant Growth of Light Judicial Review", forthcoming in C.D. Ehlermann and Mel Marquis (Eds.), European Competition Law Annual 2009: Evaluation of Evidence and Its Judicial Review in Competition Cases, Hart Publishing, 2010.
} 
Clearly, the application of competition rules involves economic reasoning, but it is not clear when such reasoning is "complex". Competition law enforcement may require assessments that are "technically" complex, such as for instance determining whether a vertically-integrated firm that is dominant on an upstream market has engaged in "margin squeeze" with the aim to foreclose downstream competitors. ${ }^{120}$ Assessing the presence of a margin squeeze involves relatively complex cost analysis, which a specialized authority is better placed to undertake than a generalist court. Moreover, some assessments may not only be complex from a technical viewpoint, but also require a policy call. A situation of this kind may, for instance, arise, in the case of distributional trade-offs, when the Commission must decide whether the anti-competitive effects of an agreement (or a proposed merger) on a particular market are outweighed by the pro-competitive efficiencies created by this transaction on another market. ${ }^{121}$

In this respect, Judge Nicolas Forwood makes a fundamentally important observation. In his view, in approaching the distinction between "complex" and "non-complex" economic appraisals, it is important "not to conflate the concept of 'complex' economic appraisals with 'difficult' economic appraisals." 122 This is because:

"[t]he mere fact that an assessment is made which requires the consideration of (possibly esoteric) economic arguments and the examination of economic evidenceeven in the substance volumes that now regularly accompany applications in the [General Court] - does not necessarily make an assessment subject to judicial review a 'complex' one, subject only to limited control, even though it may make the task of the judge extremely difficult to or burdensome."123

Judge Forwood further indicates that:

"[o]n the contrary, it could be said that what the Court of Justice had in mind, at least in the first thirty years or so of its case law, was that 'complexity' refers more to the nature of assessment that needs to be made, rather than its technical or evidential difficulty." 124

And Judge Forwood contrasts Article 101(3) assessments, which require making "value judgments", from determinations of whether an agreements falls under Article 101(1) or whether an undertaking is dominant or its conduct abusive, which do not require the Court "to depart from its default approach of a 'comprehensive review'.,"125

An interesting question is whether there is some tension between the EU Courts' ability to develop legal standards, which as we have seen above, may involve policy issues such as, for instance, whether dominant firms should be given more or less leeway when it comes to pricing - and Judge Forwood's suggestion that the General Court should not deal with assessments that requires "value judgments". Perhaps the true meaning of Judge

\footnotetext{
120 See, e.g., Commission Decision of 4 July 2007 relating to a proceeding under Article 82 of the EC Treaty (Case COMP/38.784 - Wanadoo España v Telefónica).

${ }^{121}$ Communication from the Commission - Notice - Guidelines on the application of Article 81(3) of the Treaty, OJ 2004, C 101/97.

${ }^{122}$ See Nicolas Forwood, supra note 63.

${ }^{123}$ Id.

${ }^{124} \mathrm{Id}$.

${ }^{125} \mathrm{Id}$.
} 
Forwood's suggestion is that the General Court should not be drawn into "value judgments" in the context of a given case.

Interestingly former Judge Bellamy makes a similar distinction between "facts of an economic nature", ${ }^{126}$ which as described above, refers to issues, such as whether the Commission's market definition or assessment of dominance are correct, and, another category of facts, such as those relating the Commission's balancing of anti-competitive effects with pro-competitive efficiencies in the context of an Article 101(3) assessment, which are "probably moving away from facts strictly so-called and almost entering the question of policy." "For those facts, the General Court accords "a considerable margin of appreciation to the competition authority and it is only rarely that the [General Court] will interfere [with that sort of issues]." ${ }^{128}$ Former Judge Bellamy, however, adds that, even with respect to such issues, General Court's judges have the possibility to intervene through " $a$ very convenient route known as 'defects in the reasoning' or 'défauts de motivation"' and that "is probably by that route that the decisions of the Commission are most closely controlled." 129

Indeed, the EU Courts case-law makes clear that complex economic appraisals, while perhaps subject to a less comprehensive or complete review than for issues of law and facts, will nevertheless remain intense. As the Court of Justice noted in Tetra Laval, the fact that the Commission has a margin of discretion with regard to economic matters:

"does not mean that the Community Courts must refrain from reviewing the Commission's interpretation of information of an economic nature. Not only must the Community Courts, inter alia, establish whether the evidence relied on is factually accurate, reliable and consistent but also whether that evidence contains all the information which must be taken into account in order to assess a complex situation and whether that evidence contains all the information which must be taken into account in order to assess a complex situation and whether it is capable of substantiating the conclusions drawn from it." 130

In this case, the same view, in event stronger terms, was also expressed by Advocate General Tizzano who claimed that:

"the fact that the Commission enjoys broad discretion in assessing whether or not a concentration is compatible with the common market does certainly not mean that it does not have in any case to base its conviction on solid elements gathered in the course of a thorough and painstaking investigation or that it is not required to give a full statement of reasons for its decision, disclosing the various passages of logical argument supporting the decision."131

This clearly means that, while the EU Courts are ready to recognize some leeway to the Commission, they will not authorize it to be careless in its assessments falling under the notion of complex economic appraisals. More precisely, the Tetra Laval standard of review, which focuses on four key decisional parameters, entails an intensive strict degree of judicial

\footnotetext{
${ }^{126}$ See Christopher Bellamy, supra note 111.

${ }^{127} \mathrm{Id}$.

${ }^{128} \mathrm{Id}$.

${ }^{129} I d$.

${ }^{130}$ See C-12/03 P, Commission v. Tetra Laval (“Tetra Laval II”), [2005] ECR I-987, §328.

${ }^{131}$ Opinion of Mr Advocate General Tizzano delivered on 25 May 2004, §87.
} 
scrutiny. This has been well illustrated in Airtours v. Commission. In this case, the GC quashed a Commission decision which had prohibited a merger in the short haul package holiday market on grounds on collective dominance. The GC first reviewed the factual accuracy of the Commission's evidence. It found that the decision's finding of collective dominance was erroneously based on the prediction that demand growth would be limited, whilst market trends showed a steady history of growth in the past decade. It then scrutinized the reliability of the Commission's reasoning. It found that the Commission had ignored standard economic theory in concluding that demand volatility would induce oligopolists to observe a cautious industrial strategy. It also controlled the consistency of the Commission's assessment, and found that the decision confusingly referred to vertical integration as both a pro-competitive and an anticompetitive factor. Finally, the GC lambasted the lack of exhaustiveness of the decision's reasoning. The Commission's decision had not reviewed the competitive pressure stemming from potential entry. However, the Court found that a number of firms active on the long haul package holiday market could have constrained the price policy of the (allegedly dominant) post-merger oligopoly.

In this respect, it is interesting to observe that in some relatively old cases, the European judges took an interventionist position in reviewing the economic evidence and reasoning relied upon by the Commission in competition cases. In the Wood Pulp case, for instance, the Court of Justice did not defer to the substantial body of economic evidence that had been put together by the Commission to demonstrate the existence of a concerted practice between the exporters of wood pulp to the European Union. ${ }^{132}$ It not only rejected the Commission's view that system of quarterly price announcements made by these exporters was sufficient evidence of concertation, but it hired its own experts and relied on their own reports to hold that the system of price announcements could be regarded as a rational response to the fact that the pulp market constituted a long-term market and to the need felt by both buyers and sellers to limit commercial risks.

Despite the willingness of the GC's judges to get their hands dirty and review with great care the economic evidence presented by the Commission in a number of cases - as amply illustrated by the Airtours, ${ }^{133}$ Schneider/Legrand, ${ }^{134}$ and Tetra Laval/Sidel ${ }^{135}$ judgments, ${ }^{136}$ the General Court has never made use of its ability to hire its own independent experts. In our view, this is regrettable since Wood Pulp clearly illustrated the usefulness of such experts, especially in situation where large bodies of contradictory economic evidence have been submitted by the Commission and the parties.

\section{Quantitative Assessment of the GC's Judicial Review}

Now that the principles governing the GC's judicial review are clearer, it is time to assess how the system has performed in practice. This section attempts to take an original approach of this question (Section A). It undertakes a quantitative assessment of the case-law in relation to the protection of fundamental values $(B)$ and the promotion of welfare $(C)$.

\section{A. Purpose, Background and Methodology}

\footnotetext{
132 Case C-129/85 Ahlström Osakeyhtiö and Others v. Commission, [1993] ECR I-1307.

${ }^{133}$ Case T-342/99, Airtours v. Commission, supra note 110.

${ }^{134}$ Case T-310/01, Schneider Electric v. Commission, supra note 110.

${ }^{135}$ Case T-5/02, Tetra Laval v. Commission, supra note 110.

136 See Yves Botteman, "Mergers, Standard of Proof and Expert Economic Evidence", (2006) 2 Journal of Competition Law and Economics, 71.
} 
The scholarship devoted to judicial review in EU competition law is strikingly divided. Scholars not only disagree on basic issues such as the intensity of the judicial review performed by the GC, ${ }^{137}$ but also come to polar views in respect of more specific issues. For instance, whilst some argue that the GC is reluctant to quash decisions for procedural errors, ${ }^{138}$ others consider that the GC is prompt to annul decisions for minor procedural defects. ${ }^{139}$ Finally, many of the doctrinal comments on judicial review either rely on unverifiable information or are based on subjective personal experiences, which hardly constitute "hard" scientific evidence. This is for instance true of allegations that the judicial procedure in Luxembourg is much too long. ${ }^{140}$

To avoid some of the uncertainties which contaminate discussions amongst legal scholars, this Part uses empirical data to briefly discuss two selected aspects of the GC's judicial review. ${ }^{141}$ Based on the functional approach proposed in Part I, it assesses the performance of the GC's judicial review in relation to (i) the safeguarding of fundamental values; and (ii) the promotion of welfare. However, it does not deal with the accountability function of judicial review, as this would require an investigation of the consequences of the case-law at the Commission's level. ${ }^{142}$

The present Part is based on a dataset of 207 competition judgments delivered by the GC between 1 September 2000 and 30 September $2010 .{ }^{143}$ Table I below gives an overview

\footnotetext{
${ }^{137}$ See, for instance, Saskia Lavrijssen and Maartje De Vijsser, "Independent Administrative Authorities and the Standard of Judicial Review", (2006) 1 Utrecht Law Review 2006, pp. 111-135; See also Denis Waelbroeck, "Le juge communautaire en matière de concentrations : "Censeur pédagogue" ou juge de la légalité ?", Concurrences $\mathrm{N}^{\circ}$ 4-2005, pp. 1-2 (viewing the current, and desirable, standard of judicial review as intensive). See contra, Hubert Legal, "Le contentieux communautaire de la concurrence entre contrôle restreint et pleine juridiction", Concurrences, $\mathrm{N}^{\circ} 2-2005, \mathrm{n}^{\circ} 95$, pp. 1-2.

${ }^{138}$ See John Ratliff, "Judicial Review in EC Competition Cases before the European Cours: Avoiding double renvoi", in Claus-Dieter Ehlermann and Mel Marquis (eds.), European Competition Law Annual 2009: The Evaluation of Evidence and its Judicial Review in Competition Cases, Hart Publishing, forthcoming 2010.

139 See Jurgen Schwarze, "Judicial Review of European Administrative Procedure", (2004) 69 Law and Contemporary Problems, pp. 85-105, at p. 98.

${ }^{140}$ See John Ratliff, supra note 138.

${ }^{141}$ For the sake of exhaustiveness, one should note here that the Court itself publishes yearly "statistics of judicial activity". Amongst other things, those statistics comprise general information on competition cases. The Court's statistics remain, however, highly general in nature, and thus do not provide a comprehensive account of the case-law of the GC in competition cases.

${ }_{142}$ As explained previously, there are good signs that the case-law improves "good governance", as it did in 2004 with the internal reorganization of DG Comp and the adoption of novel checks and balances mechanisms.

${ }^{143}$ The total of cases retrieved is 217. It is higher to 207 as some cases concern both Articles 101 and 102 issues It ought to be noted that the data for both years 2000 and 2010 is inevitably incomplete, given the cut-off dates that were retained (1 September 2000 and 30 September 2010). This dataset has been created by using the search device available on the website of the Court of Justice. See search form available at www.curia.eu. It concerns only cases brought to the GC, and not the ECJ. All orders and judgments responsive to the keyword "competition" have been first selected. The sample was then narrowed to judgments/orders rendered (i) on the basis of Article 263 and 261 TFEU proceedings; (ii) against infringement decisions; (iii) taken on the basis of Article 101 TFEU, Article 102 TFEU and the EU Merger Regulation. In contrast, we have excluded orders and judgments handed down in the field of State aid, as well as other orders and judgments involving other types of decisions: decisions ordering an inspection, to investigate, to seize documents, to submit complete information, and to interview employees; decisions accepting divestiture proposal; decisions rejecting proposals for a purchaser; decisions approving the acquirer of divested assets; decisions refusing to approve proposed acquirers of divested assets; decisions rejecting a demand to amend commitments imposed in a previous decisions; infringement decisions under Articles 106 and 102 TFEU; decisions imposing remedies for an infringement of Articles 106 and 102 TFEU; Article 21 EUMR decisions, decisions to refer a concentration to a Member State; decisions of the hearing officer; actions for damages against the Commission; failure to act proceedings against
} 
of this dataset, broken down per provision (Article 101 TFEU, Article 102 TFEU and EUMR). ${ }^{144}$

\begin{tabular}{|c|c|c|c|c|c|c|c|c|c|}
\hline \multicolumn{10}{|c|}{ Table I - Overview of the Dataset } \\
\hline \multirow{2}{*}{$\begin{array}{l}\text { Provision } \\
\text { Source }\end{array}$} & \multicolumn{3}{|c|}{ Article 101} & \multicolumn{3}{|c|}{ Article 102} & \multicolumn{3}{|c|}{ EUMR } \\
\hline & Total & Orders & Judgments & Total & Orders & Judgments & Total & Orders & Judgments \\
\hline 2010 & 16 & 2 & 14 & 5 & 2 & 3 & 2 & 0 & 2 \\
\hline 2009 & 17 & 3 & 14 & 2 & 0 & 2 & 5 & 2 & 3 \\
\hline 2008 & 14 & 3 & 11 & 6 & 3 & 3 & 2 & 2 & 0 \\
\hline 2007 & 10 & 2 & 8 & 8 & 0 & 8 & 2 & 1 & 1 \\
\hline 2006 & 19 & 2 & 17 & 3 & 1 & 2 & 7 & 3 & 4 \\
\hline 2005 & 14 & 2 & 12 & 1 & 0 & 1 & 3 & 0 & 3 \\
\hline 2004 & 13 & 1 & 12 & 1 & 0 & 1 & 1 & 0 & 1 \\
\hline 2003 & 16 & 1 & 15 & 6 & 0 & 6 & 4 & 0 & 4 \\
\hline 2002 & 17 & 1 & 16 & 3 & 0 & 3 & 4 & 0 & 4 \\
\hline 2001 & 10 & 1 & 9 & 2 & 1 & 1 & 0 & 0 & 0 \\
\hline 2000 & 2 & 0 & 2 & 2 & 0 & 2 & 0 & 0 & 0 \\
\hline Total & 148 & 18 & 130 & 39 & 7 & 32 & 30 & 8 & 22 \\
\hline
\end{tabular}

The approach followed draws inspiration from the early statistical work of R. Posner, ${ }^{145}$ and from the emerging stream of empirical research in EU law. ${ }^{146}$ By contrast to earlier studies, however, its scope is not limited to Article 101 TFEU, but also covers Article 102 TFEU and the EUMR. ${ }^{147}$ The present Part however leaves aside the decisional practice of the Commission. ${ }^{148}$

\section{B. Performance of the GC in relation to the Safeguarding of Fundamental Principles}

the Commission; decisions fixing the amount of a periodic penalty; decisions imposing a penalty for breach of a seal; decisions refusing the benefit of interim measures after a prohibition of a concentration, decisions imposing a separation following the prohibition of a merger; decisions interpreting commitments/undertakings; decisions to forward a non confidential version of a document to a third party; decisions on sector specific regulation issues; decisions seeking payment of a fine, decisions concerning fines to be paid back; decisions in relation to interests on fines; EUMR decisions re failure to notify; decisions rejecting demand for removal of all references to the applicant in a final decision; decisions rejecting a request to amend commitments; decisions rejecting a demand of protection of a document on the basis of legal privilege.

${ }^{144}$ The preponderance of judgments under Article 101 TFEU finds a plausible explanation in the fact that the Commission issued a large number of decisions under the notification procedure prior to 2004 as well as more generally, in cartel cases (which constitute one of its main policy priorities). Moreover, it ought to be noted that a single Article 101 decision can occasionally give rise to several judgments when appealed by distinct natural and legal persons (as is frequently the case in cartels).

${ }^{145}$ See Richard Posner, "A Statistical Study of Antitrust Enforcement", (1970) 13(2) Journal of Law and Economics, pp. 365-419.

${ }^{146}$ See Takis Tridimas and Gabriel Gari, "Winners and losers in Luxembourg: A statistical analysis of judicial review before the European Court of Justice and the Court of First Instance (2001-2005)", (2010) 35 Issue 2 European Law Review, pp. 131-173.

${ }^{147}$ See Christopher Harding and Alun Gibbs, "Why go to Court in Europe ? An Analysis of Cartel Appeals 19952004”, (2005), European Law Review, n³0, pp. 349-369 (which discusses issues related to judicial review in cartel cases).

${ }^{148}$ See for instance, Andrea Günster, Martin Carree and Maarten Peter Schinkel, "An Analysis of Court of Appeal Ruling in the EU, 1964-2000”, mimeo, 2008. 
As seen in Part I, lawyers ascribe to judicial review the function of safeguarding fundamental principles. This first function of judicial review has two variants, which can be tested separately.

\section{Protecting the Participation of Stakeholders}

Judicial review is often deemed to protect the right of all stakeholders - including minorities - to participate in the decision-making process. A possible indicator of whether the EU system of judicial review effectively performs this function consists in measuring third parties' applications to the GC. ${ }^{149}$ In this regard, Table II gives the number and rate of third party annulment applications as compared to the total number of annulment applications lodged to the GC. ${ }^{150}$ It shows that third parties initiate approximately one third of annulment proceedings in competition cases. This figure, in turn suggests that third parties perceive the $\mathrm{GC}$ as a forum where they can claim the benefit of certain rights (including participatory rights). It comes as no surprise that merger cases reach a staggering $60 \%$ rate of third party application, given the frequent complaint that third parties are marginalized in merger proceedings.

\begin{tabular}{|r|r|r|r|r|}
\hline \multicolumn{5}{|c|}{ Table II - Number and Rate of Third Party Application } \\
\hline Provision & Article 101 & Article 102 & EUMR & Total \\
\hline Total & $24 / 148(16.2 \%)$ & $19 / 39(48.7 \%)$ & $18 / 30(60 \%)$ & $61 / 217(28,1 \%)$ \\
\hline
\end{tabular}

The record of success of third parties in court is however a distinct story. Table III indicates that third parties have only rarely succeeded to challenge competition law decisions (with even a $0 \%$ success rate under Article 102 TFEU).

\begin{tabular}{|r|r|r|r|r|}
\hline \multicolumn{5}{|c|}{ Table III - Record of Success of Third Party Application } \\
\hline Provision & Article 101 & Article 102 & EUMR & Total \\
\hline Total & $3 / 24(12.5 \%)$ & $0 / 19(0 \%)$ & $2 / 18(11.1 \%)$ & $5 / 61(8.2 \%)$ \\
\hline
\end{tabular}

\section{Protecting Fundamental Principles}

A distinct, albeit related, function of judicial review is to safeguard fundamental values. Those values are not limited to procedural rights. They cover substantive principles. Hereafter, we rely on two sets of indicators to assess the performance of the GC's judicial review in relation to the protection of fundamental values of EU law (competition and other). Those indicators will help determine whether the GC is a "forum of principle", where fundamental issues (as opposed to technical issues such as market definition, etc.) are discussed.

\subsection{References to Instruments protecting Human Rights and Fundamental Freedoms}

\footnotetext{
149 However, it is imperfect, because it does not indicate whether the issue at stake involved rights of participation.

${ }_{150}$ By third party, we mean any natural or legal person external to the alleged anticompetitive conduct/transaction, including plaintiffs.
} 
With a view to obtaining a first measure of the importance of fundamental values in competition proceedings, we have scrutinized the number of references made by the GC to the EU Charter of Fundamental Rights of 7 January 2000 (the "EU Charter"), the European Convention for the Protection of Human Rights and Fundamental Freedoms ("ECtHR") and to the case-law of the ECtHR Court (see Table IV through VI below).

\begin{tabular}{|r|r|r|r|r|}
\hline \multicolumn{6}{|c|}{ Table IV - Rate of Judgments with References to the EU Charter } \\
\hline Provision & Article 101 & Article 102 & EUMR & Total \\
\hline Total & $6 / 122(4.9 \%)$ & $3 / 30(10 \%)$ & $1 / 21(4.8 \%)$ & $10 / 173(5.8 \%)$ \\
\hline
\end{tabular}

\begin{tabular}{|r|r|r|r|r|}
\hline \multicolumn{5}{|c|}{ Table V - Rate of Judgments with References to ECtHR } \\
\hline Provision & Article 7 & Article 6 & Article 4 protocol 7 & Total \\
\hline Total & $19 / 172(11 \%)$ & $18 / 172(10.5 \%)$ & $4 / 172(2.3 \%)$ & $41 / 172(23.8 \%)$ \\
\hline
\end{tabular}

\begin{tabular}{|r|r|r|r|r|}
\hline \multicolumn{6}{|c|}{ Table VI - Rate of Judgments with References to the ECtHR Case-Law } \\
\hline Provision & Article 101 & Article 102 & EUMR & Total \\
\hline Total & $4 / 122(3.3 \%)$ & $0 / 30(0 \%)$ & $0 / 21(0 \%)$ & $4 / 173(2.3 \%)$ \\
\hline
\end{tabular}

Table V shows that provisions of the ECtHR have been cited by the GC in almost a quarter of its competition judgments. The GC thus constitutes a forum where issues pertaining to human rights and fundamental freedoms are relatively frequently discussed. The fact that Table IV and VI tabulate lower data in relation to the Charter and the ECtHR case-law does not alter this finding. The Charter's somewhat limited importance in GC's judgments can be explained by its lack of binding force until the adoption of the Lisbon Treaty in 2009. In the same vein, the limited references to the ECtHR case-law find a plausible explanation in the fact that the GC, and more generally the EU Courts, have arguably sought to promote their own interpretation of fundamental rights.

\subsection{Reference to General Principles of EU Law (including Competition Law)}

The above analysis can be further refined by measuring the GC's references to general principles of EU law in competition cases. To this end, we have scrutinized the presence of two general principles of EU law (i.e., the principles of "legal certainty" and "legitimate expectations") and of one general principle of EU competition law (the reference to "free and undistorted competition" that appeared under Article $3(1)(\mathrm{g})$ of the EC Treaty) in the competition judgments of the GC.

Table VII indicates that the GC discusses general principles of law in approximately $1 / 5$ to $1 / 3$ of the competition cases brought to him. The relatively high number of cases referring to the principles of legal certainty and legitimate expectations suggest that the GC pays close attention to general principles of EU law, which generally protect the subjects of EU competition law.

\begin{tabular}{|r|r|r|r|}
\hline \multicolumn{4}{|c|}{ Table VII - Rate of judgments with reference to general principles of law } \\
\hline Principle & Legal certainty & Legitimate expectations & Undistorted competition/Article 3(1)(g) \\
\hline Total & $52 / 173(30.1 \%)$ & $34 / 173(19.6 \%)$ & $30 / 173(17.3 \%)$ \\
\hline
\end{tabular}

\footnotetext{
${ }^{151}$ Orders and inadmissibility judgments excluded.
} 


\section{Conclusion}

The above indicators show that the GC is, occasionally, a "forum of principle" where fundamental values can be, and are, discussed. One can thus safely assume that the case-law of the GC is effective in fulfilling the "rights-based" function ascribed by lawyers to judicial review.

This notwithstanding, our dataset also shows that a vast majority - around $2 / 3$ - of the competition cases heard by the GC primarily involve standard competition law discussions, rather than fundamental issues. In essence, this tends to indicate that the "rights-based" function of judicial review is not the GC's primary function.

\section{Performance of the GC in relation to the Promotion of Welfare}

This section does not seek to statistically measure the performance of the GC in relation to the setting of normative legal standards. Over the past decades, the GC, and more generally the EU Courts have set very many substantive standards of EU competition law. Whether the EU Courts have satisfactorily discharged their setting of normative standards function is, however, primarily a qualitative question that cannot be measured empirically. The case-law of the GC is indeed replete with normative standards, but - with some limited exceptions discussed below - numbers say little about whether those standards allow the GC, the Commission, NCAs and national courts to adopt sound, welfare enhancing decisions. In Part $\mathrm{V}$, we seek to provide an answer to these questions by taking a qualitative approach to the GC's case-law.

What this section does is to assess the performance of the GC in relation to the elimination of decisional errors. In his seminal paper, Shavell argues that applicants only launch proceedings against unlawful decisions. ${ }^{152}$ Hence, a welfare-enhancing judicial review system - one which eradicates all decisional errors - should reverse all challenged decisions. Shavell's demonstration is however based on a theoretical, unrealistic model. An optimal $100 \%$ annulment rate cannot be observed in practice, simply because annulment applicants often erroneously (or opportunistically) challenge lawful decisions. That said, Shavell's article implies that a welfare-enhancing system of judicial review will at least quash a minimum number of negative decisions. ${ }^{153}$ According to Alhborn, Evans and Padilla, this should be particularly so in competition cases, where Type I errors are likely and pervasive.

In this context, table IX shows that the EU judicial system fulfills, at least to a certain extent, its welfare-enhancing function of eradicating Type I decisional errors in the field of merger control (4 annulments out of 7 incompatibility decisions) and Article 101 TFEU (31 annulments out of 117 infringement decisions).

Table IX - Number of Annulment Judgments on Incompatibility/Infringement Decisions

\begin{tabular}{|r|r|r|r|} 
Provision & EUMR & Article 101 & Article 102 \\
\hline
\end{tabular}

\footnotetext{
152 This is in line with the argument developed by Shavell, supra note 16. Applicants will not launch proceedings against lawful decisions, on pain of losing time and money in useless proceedings.

${ }^{153}$ It is impossible to set the optimal rate of annulments at which a judicial review system can be said to promote welfare (in eradicating decisional errors).
} 


\begin{tabular}{|r|r|r|r|}
\hline \multirow{3}{*}{ Total } & $4 / 7$ & $31 / 117$ & $4 / 14$ \\
& $(57.1 \%)$ & $(26.5 \%)$ & (partial: 4) \\
& (full:4) & (partial: 23) & (full: 0) \\
\hline
\end{tabular}

However, this conclusion is not warranted in relation to Article 102 TFEU. In this field indeed, no decision was ever annulled in full, and the few annulled decisions were only partially quashed. Moreover, a close examination of those cases reveals that the GC only stroke down peripheral aspects of the Commission's decisions and upheld their main substantive findings. ${ }^{154}$ This situation stands in stark contrast with judgments adopted under the EUMR, where 4 out the 7 Commission decisions were annulled in full, on substantive grounds. ${ }^{155}$ It is also inconsistent with the case-law under Article 101 TFEU, where 8 decisions were annulled in full, also on substantive grounds.

The disconcerting finding that the Commission enjoys a relative degree of judicial immunity in Article 102 TFEU cases is corroborated by Table X. The GC exhibits a clear willingness to reduce the fines imposed for infringements of Article 101 TFEU, with almost $45 \%$ of applications leading to a fine reduction. In contrast, under Article 102 TFEU, only 2 out of 11 cases have given rise to a reduction of the fine.

\begin{tabular}{|r|r|r|}
\hline \multicolumn{5}{|c|}{ Table X - Number and Rate of Revised Fines on article 261 Applications } \\
(on fines grounds only)
\end{tabular}

Moreover, as explained previously, no third party ever managed to successfully challenge a Commission Article 102 TFEU decision.

Overall, the trivial rate of annulment judgments under Article 102 TFEU is disturbing. It casts doubt on the effectiveness of the GC's judicial review in eliminating type I errors. Of course, the Commission may well have been right in all cases appealed to the GC. Yet, in our opinion, this "success story" hypothesis does not withstand scrutiny. It is indeed contradicted by the existence of several harsh annulment judgments in all other areas of competition law (and, in particular in areas where (i) negative decisions are less frequent; and (ii) the Court grants to the Commission a large margin of discretion/error tolerance).

A more plausible explanation to the absence of full annulment of Commission decisions adopted in Article 102 TFEU has to do with the GC's conservatism, or put differently, its habit of restating, rather than questioning, old, formalistic legal appraisal standards, and its reluctance to endorse a modern economic approach. As a result, the

\footnotetext{
${ }^{154}$ See T-325/01, AstraZeneca v. Commission, not yet reported; T-66/01,Imperial Chemical Industries (ICI) $v$ Commission, not yet reported; T-201/04, Microsoft v. Commission, [2007] ECR II-03601, and T-191/98, Atlantic Container Lines v. Commission, [2003] ECR II-03275. In several of those cases, the GC's grounds for annulment concern peripheral issues. In ICI v. Commission, the GC annulled the fine in relation to the year 1983. In Microsoft, the annulment concerned the delegation of monitoring duties to a trustee. Finally, Atlantic Container Lines is a somewhat unusual abuse of dominance case, which concerned primarily unlawful agreements that had benefited from an exceptional exemption under a particular sector specific framework.

${ }^{155}$ See Airtours v. Commission, supra note 110; Tetra Laval v. Commission, supra note 110; and Schneider v. Commission, supra note 110. In contrast, the GC ruling in MCI v. Commission, T-310/00 involves an annulment on grounds of lack of competence.
} 
Commission's Article 102 TFEU decisions are subject to lenient - one would say deficient judicial scrutiny, and systematically avoid annulment in Luxembourg. One could of course argue that most of those standards were set by the ECJ, and it is not for the GC to set different normative standards. Yet, this has not prevented, in the past, the GC to promote normative standards that differed, and in fact effectively modernized, the case-law of the ECJ. Those aspects will be specifically discussed in Part V.

To test the veracity of this hypothesis, we have scrutinized two sets of original parameters. First, we have measured the degree of reliance of the GC on old precedents in abuse of dominance cases. This research produces interesting results. Table XI shows that the most popular judgment in the case-law of the GC is Michelin II (31 quotes in 16 different judgments). Yet, this judgment is also one of the most controversial judgments in the history of competition scholarship. Michelin II is indeed almost unanimously described as a striking piece of formalism, devoid of any economic sense. ${ }^{156}$

The second most cited case is Hoffman La Roche v. Commission (23 quotes out of 14 judgments). This ruling is one of the oldest judgments rendered under Article 102 TFEU (it was handed down in 1979). It enshrines an abstract - one would say hollow - definition of dominance and abusive behavior that makes little, if no sense from an economic perspective. Interestingly, those cases were still the two most cited precedents in the judgments delivered in 2010 .

\footnotetext{
${ }^{156}$ See Damien Geradin, supra note 54.
} 


\begin{tabular}{|c|c|c|c|c|c|c|c|c|c|c|c|c|}
\hline \multicolumn{13}{|c|}{ Table XI - Quotes of Case-Law Precedents in Article 102 TFEU Judgments } \\
\hline & $\begin{array}{l}\text { Hoffma } \\
\text { nn-La } \\
\text { Roche } \\
\text { /Com }\end{array}$ & $\begin{array}{l}\text { Suik } \\
\text { er } \\
\text { Unie } \\
\text { e.a. } \\
\text { /co } \\
\text { m } \\
\end{array}$ & $\begin{array}{c}\text { United Brands } \\
\text { and United } \\
\text { Brands } \\
\text { Continental/Co } \\
\text { m }\end{array}$ & \begin{tabular}{|l} 
Micheli \\
$\mathrm{nI}$ \\
/Com
\end{tabular} & $\begin{array}{c}\text { Microsoft/C } \\
\text { om }\end{array}$ & $\begin{array}{c}\text { Micheli } \\
\text { n } \\
\text { II/Com }\end{array}$ & \begin{tabular}{|c|} 
France \\
Télécom/Co \\
$\mathrm{m}$
\end{tabular} & $\begin{array}{c}\text { Tetr } \\
\text { a } \\
\text { Pak } \\
\text { II }\end{array}$ & $\begin{array}{c}\text { British } \\
\begin{array}{c}\text { Airways/Co } \\
m\end{array}\end{array}$ & $\begin{array}{c}\text { Tetr } \\
\text { a } \\
\text { Pak }\end{array}$ & $\begin{array}{c}\text { AKZO/Co } \\
m\end{array}$ & $\begin{array}{l}\text { Number } \\
\text { of } \\
\text { judgmen } \\
\text { ts }\end{array}$ \\
\hline 2010 & 9 & 3 & 2 & 5 & 3 & 10 & 1 & 0 & 2 & 2 & 3 & 3 \\
\hline 2009 & 5 & 1 & 1 & 1 & 5 & 10 & 0 & 0 & 2 & 1 & 1 & 2 \\
\hline 2008 & 1 & 0 & 0 & 0 & 0 & 0 & 1 & 0 & 0 & 0 & 2 & 2 \\
\hline 2007 & 2 & 0 & 2 & 0 & 0 & 3 & 0 & 6 & 0 & 10 & 7 & 4 \\
\hline 2006 & 0 & 0 & 0 & 0 & n/a & 0 & n/a & 0 & 0 & 0 & 0 & 0 \\
\hline 2005 & 0 & 0 & 0 & 0 & n/a & 0 & n/a & 0 & 0 & 0 & 0 & 0 \\
\hline 2004 & 0 & 0 & 0 & 0 & n/a & 0 & n/a & 0 & 0 & 0 & 0 & 0 \\
\hline 2003 & 5 & 1 & 1 & 0 & n/a & 8 & n/a & 0 & 0 & 0 & 0 & 3 \\
\hline 2002 & 0 & 0 & 0 & 0 & n/a & n/a & n/a & 0 & $\mathrm{n} / \mathrm{a}$ & 0 & 0 & 0 \\
\hline 2001 & 0 & 0 & 0 & 0 & n/a & n/a & n/a & 0 & $\mathrm{n} / \mathrm{a}$ & 0 & 0 & 1 \\
\hline 2000 & 1 & 0 & 0 & 0 & $\mathrm{n} / \mathrm{a}$ & n/a & n/a & 0 & n/a & 3 & 0 & 1 \\
\hline Total & 23 & 5 & 6 & 6 & 8 & 31 & 2 & 6 & 4 & 16 & 13 & 14 \\
\hline
\end{tabular}

Second, we have examined the GC's openness to mainstream economic concepts in the context of its Article 102 TFEU case-law. To this end, we have selected 14 conventional economic terms from the OECD Glossary of Industrial Organisation Economics and Competition Law. ${ }^{157}$ In turn, we have searched those concepts in the text of the 30 abuse of dominance judgments handed down by the GC. Table XII records the result of this research.

157 See OECD Glossary of Industrial Organisation Economics and Competition Law, available at http://www.oecd.org/dataoecd/8/61/2376087.pdf 


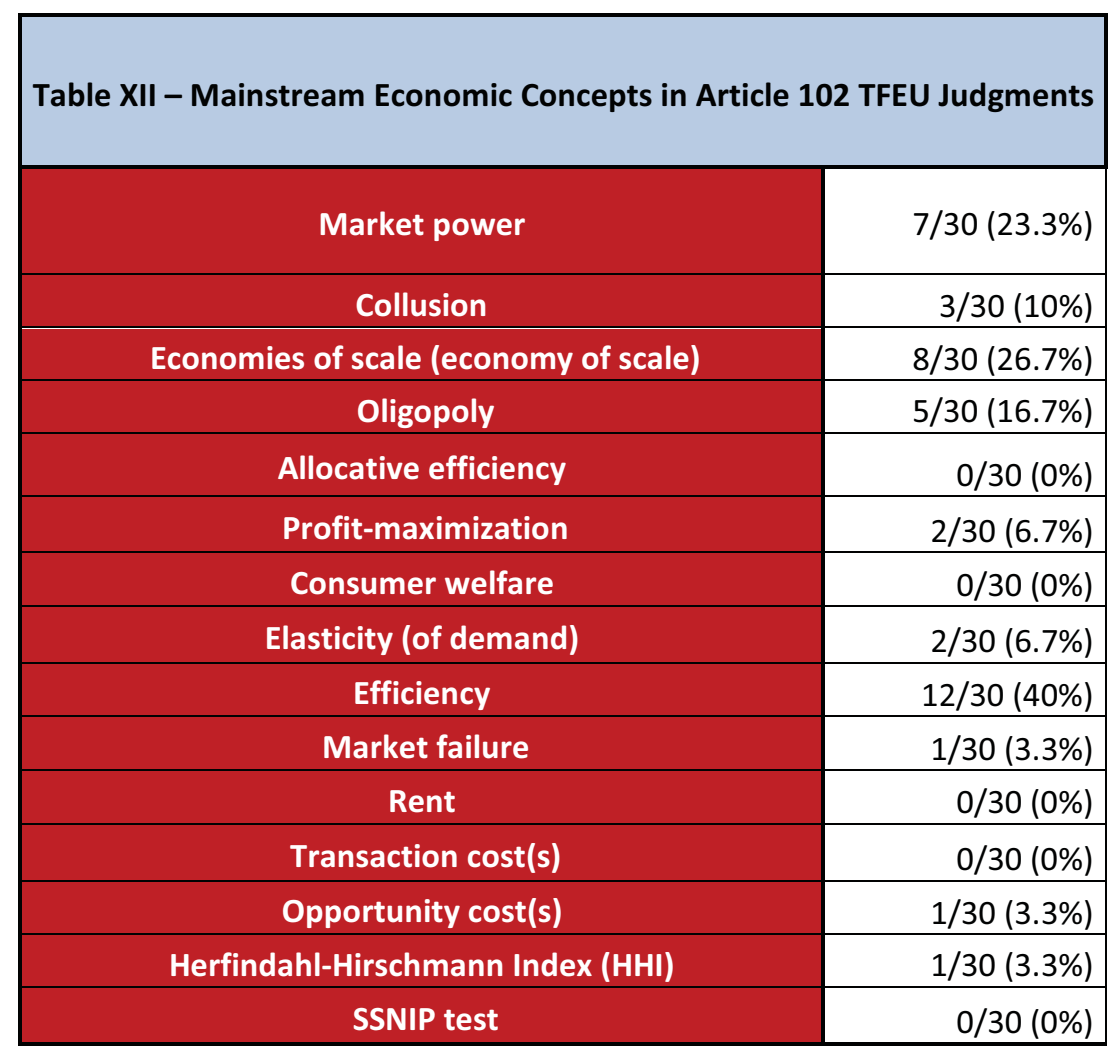

Clearly, this table shows that the GC is reluctant to accommodate mainstream economic concepts within the realm of the Article 102 TFEU case-law. For instance, the concept of "consumer welfare", which has been elevated as the alpha and omega of competition policy in Europe and in the US, is not even cited once in the Article 102 TFEU case-law of the GC. The same holds true of the SSNIP test, or to a lesser extent of the HHI Index, which however constitute conventional instruments for the assessment of a dominant position.

Those two indicators tend to corroborate empirically the hypothesis that the GC is reluctant to embrace an economic approach in the area of abuse of dominance (and that it intends to stick to old, legalistic solutions). In so doing, the GC arguably maintains a misplaced approach of abuse of dominance law, which insulates Commission decisions from judicial scrutiny.

\section{A Qualitative Analysis of the "Setting of Normative Standards" Function in the Case-Law of the General Court}

As noted in Part IV, one of the functions of judicial review that cannot be fully tested in an empirical manner relates to the adoption of normative legal standards. Of course, our data shows that the GC has been quite impermeable to basic - yet critically important economic concepts (such as "consumer welfare") and has had a tendency to repeat the old formalistic standards adopted by the ECJ in landmark - although controversial - cases, such as Hoffman-La Roche and Michelin II. But these observations are not sufficient to a take firm stance on the fundamental question of whether the GC has played an important role in the definition of normative standards or has merely repeated, and relied, on well-established caselaw. As will be seen below, this issue essentially depends on whether we look at the case-law of the GC with respect to Article 101, 102 and the EUMR. 
In areas such as Article 101 and the EUMR, the GC has been keen to define, and refine, normative legal standards in light of modern economic theory (and in particular, the so-called "effects-based approach"), including when this entailed reversing decades of earlier case-law. The GlaxoSmithKline v. Commission case brings a salient illustration of this. In this ruling, the GC challenged the legalistic (and economically unverified) principle that agreements limiting parallel trade shall be presumed anti-competitive by "object". ${ }^{158}$ According to the GC, no conclusion on this issue can be attained absent an analysis of the agreement's effects on the welfare of consumers. ${ }^{159}$ Similarly, the GC's ruling in Airtours $v$. Commission constitutes a striking piece of modern judicial rule-making. In this case, the GC aligned the law of collective dominance on the - complex - economics of tacit collusion. Of course, the principles enshrined in those rulings have had a different fate (the ECJ quashed the GlaxoSmithKline judgment, but confirmed the Airtours $v$. Commission ruling in following cases). ${ }^{160}$ But those cases, alongside others, clearly denote the GC's willingness to "progress" normative standards under Article 101 TFEU and EUMR cases. ${ }^{161}$

Against this background, it is hard to identify a similar dynamic in cases involving appeals of Commission decisions adopted on the basis of Article 102 TFEU where the judgments adopted by the GC tend to rely on the formalistic - and poorly in line with economics - legal standards adopted by the ECJ. ${ }^{162}$ In our review, the reliance on such standards may to a significant extent explain why the case-law of the GC in the field of abuse of dominance has been so unfavorable to undertakings appealing Commission decisions.

In our opinion, the fact that undertakings challenging Article 102 TFEU decisions of the Commission almost systematically lose before the GC is not due to the fact that the Court would apply weaker standards of review to abuse of dominance cases (judgments such as Microsoft review in excruciating details the challenged Commission decision), ${ }^{163}$ but that the normative legal standards relied upon by the GC to assess the compatibility of dominant firm practices with Article $102 \mathrm{TFEU}$, and the way the GC applies such standards when reviewing a Commission decision, are generally inadequate. As will be seen below, the legal tests developed by the Court of Justice in the field of abuse of dominance are sometimes so strict that they can almost accommodate any decision of the Commission even if it appears poorly in line with elementary economics. ${ }^{164}$ In other words, the problem is not one of judicial deference in the degree of control exercised by the GC with respect of abuse of dominance decisions, but one of defective rule-making in that the legal standards relied upon by the Court are out of touch with contemporary economics (and even in some cases with basic common sense).

\footnotetext{
${ }^{158}$ See Nicolas Petit, "The Economics of Parallel Trade - Iconoclast Views on a Dogma of EU Competition Law", (August 19, 2010), available at SSRN: http://ssrn.com/abstract=1661884.

159 See T-168/01,GlaxoSmithKline Services against Commission, [2006] ECR II-02969, §§117-199.

${ }^{160}$ See C-413/06 P, Bertelsmann AG and Sony Corporation of America v. Impala, [2008] ECR I-4951.

${ }^{161}$ See, for instance, T-112/99, Métropole télévision (M6) and others, [2001] ECR II-2459, which is extensively cited in the Commission's Guidelines on Article 101(3) TFEU as a key precedent for the analysis of ancillary restraints, etc.

162 For a criticism of such standards, see Nicolas Petit, "From formalism to effects - The Commission's Guidance Communication on Article 82 EC", (2009) 32-4 World Competition - Journal of Law and Economics, pp. 485-503; see also Jean-Yves Art and Pablo Ibáñez Colomo, "Judicial Review in Article 102", in Etro \& Kokkoris (Eds), Competition Law and the Enforcement of Art. 102, forthcoming Oxford Univ. Press, 2010.

${ }^{163}$ See T-201/04, Microsoft v. Commission, 2007 ECR II-3601. This judgment was extremely long and detailed and comprised no less than 1373 paragraphs.

${ }^{164}$ See Jean-Yves Art and Pablo Ibáñez Colomo, supra note 164.
} 
Although examples abound, a few well-known problems bring sufficient illustrations of this. Let us, for instance, look at tying, which is a common - and generally efficiencyenhancing - commercial practice used by both dominant and non-dominant firms. ${ }^{165}$ Pursuant to the ECJ case-law, in order to establish that a combination of products by a firm that is dominant on one such product (the "tying" product) infringes Article 102, the Commission must demonstrate: (i) the presence of two distinct products in that there is separate demand for the "tied" product; (ii) coercion in that the dominant firm does not give consumers the option of obtaining the tying product without the tied product; and (iii) foreclosure in that rivals on the market for the tied product are excluded; and (iv) the lack of objective justification of sufficient countervailing efficiencies. ${ }^{166}$ Let us now look at whether this test, and in particular its first two elements, makes sense.

The first element of the test whereby two products are distinct if there is separate demand for the tied product make little, if no economic sense. Taken literally, it might lead one to conclude that mobile telephones and ring tones, PCs and keyboards, and MP3 players and earphones are all distinct products, despite the fact that consumers clearly see them as forming part of a single product. As correctly observed by the applicant in the Microsoft case, ${ }^{167}$ the correct test is that two products are distinct if there is no separate consumer demand for both the tying and the tied product. Indeed, it is perfectly possible for there to be separate demand for ring tones without a mobile telephone, but there is surely no demand for a mobile telephone without a ring tone. Hence, unless this test, which the EU Courts have repeatedly affirmed in their case-law, is changed, there is a considerable risk that perfectly benign combination of products be caught as tying with the meaning of Article 102 TFEU (a Type I error).

The second element of the test, according to which there is coercion when the dominant firm does not give the option of buying the tying product without the tied product, does not fare better. This test makes sense in certain circumstances, but does not in others. Clearly, if a customer cannot acquire a printer (the tying product) without buying a large quantity of paper (the tied product) from the printer manufacturer, that customer will not purchase paper from the manufacturers' competitors, at least for a certain period of time. In these circumstances, which were present in the seminal Hilti and Tetra Pak judgments, ${ }^{168}$ the

\footnotetext{
${ }^{165}$ Generally on tying, see Robert O'Donoghue and Jorge Padilla, The Law and Economics of Article 82 EC, 2006, Chapter 9.

${ }^{166}$ See C-333/94 P, Tetra Pak II, [1996] ECR I-5951 and T-30/89, Hilti, [1991] ECR II-1438.

167 See T-201/04, supra note 163, §887 ("Microsoft takes issue with the fact that in the contested decision the Commission considers only the question whether what it alleges to be the tied product, namely media functionality, is available separately from what it alleges to be the tying product, namely the client PC operating system. In reality, the appropriate question is whether the tying product is regularly offered without the tied product. In fact, there is no real consumer demand for a client PC operating system without media functionality and no operator therefore markets such a system.")

${ }^{168}$ In both Hilti and Tetra Pak II, supra note 168, the finding of unlawful tying hinged on the fact that the tie in question prevented consumers from acquiring the tied product from other sources. In Tetra Pak II, consumers purchasing a Tetra Pak packaging machine had to commit also to buy their requirements of carton from Tetra Pak. In Hilti, consumers could buy Hilti's proprietary cartridge strips only if they also bought the corresponding complement of nails. Even if consumers were not formally required to source all their requirements of nails from Hilti, that was the practical consequence. Nails and fastening tools are expensive, and for obvious reasons, consumers had no incentive to purchase more nails than they needed, namely one per cartridge. Nails for Hilti cartridge strips were "rival goods". The use of Hilti nails thus necessarily excluded the use of their-party nails and foreclosed competition. In these cases, consumers of the tied product were locked-in and thereby deprived of their freedom of choice.
} 
customer is clearly coerced to buy the dominant firm's paper and rival paper makers are foreclosed. In contrast, in the settings that were at stake in the two Microsoft cases (Windows Media Player and Internet Explorer (IE)), ${ }^{169}$ the test used by the EU Courts is flawed. It is indeed not because a customer buying Windows also automatically acquires IE that this customer is coerced. Unlike in the prior example, nothing prevents this customer from acquiring as many rival browsers as he wishes and many computer users have different browsers on their computers (a practice called "multi-homing"). Clearly, the test of coercion applied by the EU Courts is too broad and should be limited to situations where the tie makes it significantly more difficult (if only financially) for the customer to purchase or consume a rival version of the tied good.

The legal standards applied by the EU Courts to rebates have also been a source of considerable criticisms, but they have rigorously applied by the GC. This can be illustrated by looking at the recent judgment of the GC in Tomra, which not only faithfully repeats the controversial case-law of the ECJ in the area of rebates (Hoffman La-Roche, Michelin II, etc.), ${ }^{170}$ but to some extent makes it even worse. ${ }^{171}$ This judgment stems from an appeal lodged by Tomra, a company that produces automatic recovery machines for empty beverage containers (reverse vending machines ("RVMs")), against a Commission decision finding that it had infringed Article 102 TFEU by implementing an exclusionary strategy in several national RVM markets, involving exclusivity agreements, individualised quantity commitments and individualised retroactive rebate schemes, thus foreclosing competition on the markets. ${ }^{172}$ The General Court's discussion of the compatibility of Tomra's rebates with Article 102 is interesting as it summarizes the legal tests adopted by the EU Courts with respect to the "loyalty" rebates in prior judgments.

According to the General Court:

"with more particular regard to the granting of rebates by an undertaking in a dominant position, it is apparent from a consistent line of decisions that a loyalty rebate, which is granted in return for an undertaking by the customer to obtain his stock exclusively or almost exclusively from an undertaking in a dominant position, is contrary to Article 82 EC." 173

It is undeniably true that loyalty rebates may produce exclusionary effects. Whether or not such effects occur can, however, only be determined on the basis of a price-costs analysis

\footnotetext{
${ }^{169}$ See "Commission confirms sending a Statement of Objections to Microsoft on the tying of Internet Explorer to Windows", MEMO/09/15, 17 January 2009 (confirming that the Commission had sent to Microsoft a SO and outlining the Commission's preliminary view that Microsoft's tying of its web browser Internet Explorer to its dominant client PC operating system Windows infringes the EC Treaty rules on abuse of a dominant position (Article 82)). This case was eventually settled through a so-called Article 9 decision of the Commission. See "Commission accepts Microsoft commitments to give users browser choice", IP/09/1941, 16 December 2009 (confirming that the Commission had adopted a decision that renders legally binding commitments offered by Microsoft to boost competition on the web browser market)

${ }^{170}$ On this case-law, see, e.g., Denis Waelbroeck, "Michelin II : A Per Se Rule against Rebates by Dominant Companies?", (2005) 1 Journal of Competition Law and Economics, pp. 149-171.

${ }^{171}$ See T-155/06, Judgment of the General Court of 9 September 2010, not reported yet.

${ }^{172}$ See Commission Decision C(2006) 734 final of 29 March 2006 relating to proceedings under Article 82 [EC] and Article 54 of the EEA Agreement (Case COMP/E-1/38.113 - Prokent-Tomra).

${ }^{173}$ See T-155/06, supra note $173, \S 210$.
} 
of the type proposed by the Commission in its Guidance Paper on Article 102 TFEU. ${ }^{174}$ While the General Court acknowledges that the Commission has performed such an analysis, it restates the traditional case-law whereby "the actual effects of the applicants " practices" do not have to be demonstrated by the Commission to establish an infringement as loyalty rebates are "liable to" restrict competition. ${ }^{175}$ Although the Commission has been conducting price-costs tests in its more recent rebates cases, it does not make a difference whereas these tests are properly conducted as in any event loyalty rebates are per se illegal.

But this is not the only part of the judgment (or, more generally, the case law of the EU Courts on rebates) that is subject to criticism. Indeed, as correctly observed by Tomra in its appeal, even if the contested decision had demonstrated that all the agreements in question might have had foreclosure effects, that would prove only that competitors would have been foreclosed from supplying customers which had already concluded those agreements. ${ }^{176}$ Nothing would have prevented Tomra's rivals to supply the remaining customers. Indeed, the fact that a given rebate forecloses one or several competitors of the dominant firm from supplying one or several customers is not sufficient to demonstrate the presence of anticompetitive effects. Such effects will only appear when such customers represent a substantial share of the market that is critical for rivals' competitiveness. Otherwise, even if they are unable to supply one or several customers, rivals will have access to a sufficient share of the demand for the products/services in question to allow them to profitably enter or remain on the market, and thus constrain the dominant firm.

Yet, in one of the most extraordinary statements ever made in a competition law judgment, the General Court states that:

"the foreclosure by a dominant undertaking of a substantial part of the market cannot be justified by showing that the contestable part of the market is still sufficient to accommodate a limited number of competitors. ... the customers on the foreclosed part of the market should have the opportunity to benefit from whatever degree of competition is possible on the market and competitors should be able to compete on the merits for the entire market and not just for a part of it." 177

That position is entirely untenable as, taken literally, it suggests that if a dominant firm grants loyalty rebates to customers whose combined purchases amount to ten percent of the market (hence, leaving the other ninety percent to rivals), that firm would have nevertheless committed an abuse. Moreover, this sort of disastrous statement goes entirely against the efforts by the Commission, and some national competition authorities, to move away from a legalistic approach of enforcing Article 102 TFEU to an effects-based one.

Clearly, the EU Courts' case-law on tying and loyalty rebates, but this is also true in other areas of abuse of dominance law, not only is incongruent with effects-based reform, but truly plays against it by validating formalistic analyses. In fact, this case-law signals the Commission and national competition authorities that, although they are free to engage in

\footnotetext{
${ }^{174}$ See Guidance on the Commission's Enforcement Priorities in Applying Article 82 EC Treaty to Abusive Exclusionary Conduct by Dominant Undertakings, 3 December 2008, available at http://ec.europa.eu/competition/antitrust/art82/guidance.pdf

${ }^{175}$ See T-155/06, supra note 171, §219.

${ }^{176}$ See Damien Geradin, supra note 54.

${ }^{177}$ See Case T-155/06, supra note 171, §219.
} 
effects-based analysis, this analysis is not essential to a finding of infringement and even if it ends up being flawed that will not jeopardize the viability of their decision in appeal.

\section{Conclusions}

While the vast majority of the legal literature on the judicial review of competition cases by the EU Courts has focused on the scope and intensity of that review on Commission decisions, this paper has sought to bring a different approach by first identifying the functions attributed by the legal, economic and political science literature to judicial review to then analyze through a combination of quantitative and qualitative analysis the extent to which the $\mathrm{GC}$ has discharged these functions.

Our main findings are that while the GC has applied a demanding standard of review to Commission decisions, including with respect to issues of "complex economic appraisals", and has reasonably discharged its function of "protecting fundamental issues", its record is mixed with respect to the "promotion of welfare" and the "development of normative legal standards". First, while our empirical data shows that the GC struck down an important number of Article 101 and merger control decisions, it indicates that the GC has shown deference to the Commission in Article 102 cases. Second, our qualitative analysis of the GC case-law suggests that while with respect to Article 101 and merger decisions the GC has been keen to define, and refine, normative legal standards in light of modern economic theory (and in particular, the so-called "effects-based approach"), including when this entailed reversing decades of earlier case-law, it has adopted a conservative attitude in Article 102 decisions essentially relying on the formalistic - and poorly in line with economics - legal standards adopted by the ECJ. That approach is likely to have a negative impact on welfare by increasing the risk of prohibition of benign dominant firm conduct for the sole reason that such conduct falls under the formalistic standards developed by in the case-law of the ECJ. It also risks harming the efforts made by the Commission and national competition authorities to promote effects-based approaches by legitimizing decisions based on per se standards. Clearly, the GC needs to modernize the legal standards applied to dominant firm conduct as it has done with respect to Article 101 and, perhaps even more clearly, merger decisions. Abuse of dominance law needs an Airtours. 